\title{
Virulence
}

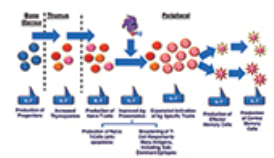

\section{Aging and sex hormones in males}

\section{Maria Chiara Decaroli \& Vincenzo Rochira}

To cite this article: Maria Chiara Decaroli \& Vincenzo Rochira (2017) Aging and sex hormones in males, Virulence, 8:5, 545-570, DOI: 10.1080/21505594.2016.1259053

To link to this article: http://dx.doi.org/10.1080/21505594.2016.1259053

Accepted author version posted online: 10

Nov 2016.

Published online: 10 Nov 2016.

Submit your article to this journal $\pi$

III Article views: 545

Q View related articles $\sqsubset$

View Crossmark data $־$

47 Citing articles: 3 View citing articles 진 


\title{
Aging and sex hormones in males
}

\author{
Maria Chiara Decaroli ${ }^{\mathrm{a}}$ and Vincenzo Rochira (D) $^{\mathrm{a}, \mathrm{b}}$ \\ ${ }^{a}$ Unit of Endocrinology, Department of Biomedical, Metabolic and Neural Sciences, University of Modena and Reggio Emilia, Modena, Italy; \\ ${ }^{\mathrm{b}}$ Azienda USL of Modena, Modena, Italy
}

\section{ABSTRACT}

Several large cohort studies have disclosed the trajectories of sex steroids changes overtime in men and their clinical significance. In men the slow, physiological decline of serum testosterone (T) with advancing age overlaps with the clinical condition of overt, pathological hypogonadism. In addition, the increasing number of comorbidities, together with the high prevalence of chronic diseases, all further contribute to the decrease of serum T concentrations in the aging male. For all these reasons both the diagnosis of late-onset hypogonadism (LOH) in men and the decision about starting or not $T$ replacement treatment remain challenging. At present, the biochemical finding of $T$ deficiency alone is not sufficient for diagnosing hypogonadism in older men. Coupling hypogonadal symptoms with documented low serum $T$ represents the best strategy to refine the diagnosis of hypogonadism in older men and to avoid unnecessary treatments.
ARTICLE HISTORY

Received 13 May 2016

Revised 3 November 2016

Accepted 7 November 2016

\section{KEYWORDS}

bone mineral density; estradiol; late-onset hypogonadism ( $\mathrm{LOH})$; menopause; replacement treatment; sex steroids; testosterone

\section{Introduction}

Aging is associated with changes in the physiological functioning of the endocrine system. ${ }^{1}$ Except for the thyrotropin hormone (TSH) that tends to increase with advancing age, the secretion of other pituitary hormones such as growth hormone (GH) and prolactin progressively decreases with aging. ${ }^{1}$ The same happens to insulin-like growth factor-1 (IGF-1), which is directly regulate by $\mathrm{GH} .{ }^{1}$

The aging of the reproductive function is characterized by the loss of function of gonads that occurs as an on/off phenomenon in females at the time of menopause. $^{1,2}$ (Fig. 1). Vice versa, in aging males, the reproductive function progressively declines in parallel with the decrease of testicular function year by year ${ }^{1}$ Accordingly, gonadotropins slightly increase in men while definitely soar at the time of menopause in women. ${ }^{1}$ In men, however, also a decline of gonadotropic cell function has been documented in a significant percentage of aging men. ${ }^{3}$

As far as sex hormones are concerned, it should be remarked that their production is different in men and women during adulthood: serum testosterone $(\mathrm{T})$ is 10 folds higher in men than in women, while serum estradiol $\left(E_{2}\right)$ declines after the fifties in both sexes; thus sex hormones changes during aging differ by gender (Fig. 1).
Gender differences in aging related decline of sex hormones are outlined in Figure 1.

\section{Physiological decline of serum $T$ with advancing age in men}

Serum total $\mathrm{T}$ declines with advancing age with a rate that has been estimated to be about $1-2 \%$ per year from the third decade onward. ${ }^{45}$ (Fig. 1). This rate of decline in serum $\mathrm{T}$ corresponds approximately to a reduction of $3.2-3.5 \mathrm{ng} / \mathrm{dL}(0.110-0.121 \mathrm{nmol} / \mathrm{L})$ per year ${ }^{4,6}$ At the age of $75 \mathrm{y}$ a men has already lost about $30 \%$ of his circulating quote of $\mathrm{T}$ measured at the age of 25 years., According to different studies, the prevalence of low total $\mathrm{T}$ in men over $60 \mathrm{y}$ is, on average, around $20 \%$ to $30 \%$ and it constantly increases with aging. ${ }^{3-5,8-10}$

The total amount of circulating serum $\mathrm{T}$ corresponds to the total serum $\mathrm{T}$ usually assayed into the clinic, which is the sum of both free $\mathrm{T}$ and $\mathrm{T}$ bound to serum proteins. ${ }^{11}$ Serum free $\mathrm{T}$ represents the circulating fraction that is completely unbound and promptly available for binding the androgen receptor in target tissues; it is, however, a small part of circulating serum $\mathrm{T}^{11}$. A minimal part of circulating $\mathrm{T}$ bounds albumin and the strength of this binding is weak. ${ }^{11}$ For this reason, serum

CONTACT Vincenzo Rochira vincenzo.rochira@unimore.it Unit of Endocrinology, NOCSAE, Via P. Giardini 1355, 41126 Modena, Italy. 


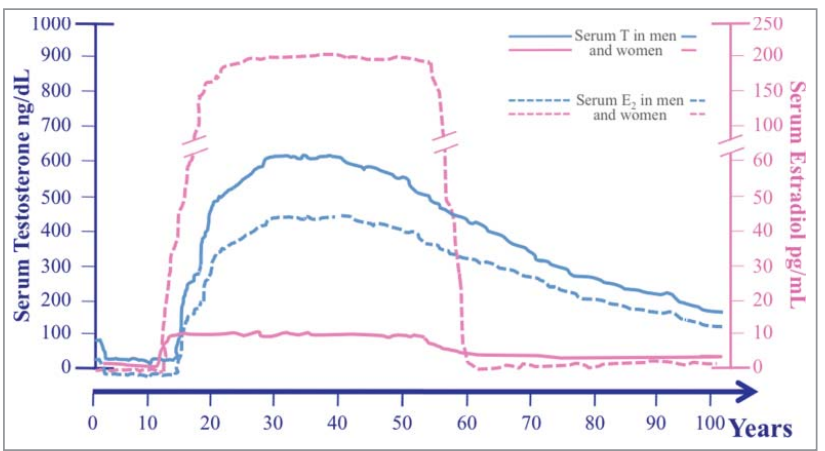

Figure 1. Serum levels of both testosterone (T) (solid lines) and estradiol $\left(E_{2}\right)^{*}$ (broken lines) across the lifespan in men (blue lines) and women (pink lines). Data used for plotting age-related sex steroids changes in both sexes have been derived from Kaufman \& Vermeulen $2005^{5}$, Zmuda et al. $1997^{6}$ (for men), and from Al-Safi et al. $2000^{2}$ and Veldhuis 2013 (for women). serum $E_{2}$ levels of premenopausal women are represented as the mean of E2 measured during the different phases of the menstrual cycle; T: testosterone; $E_{2}$ : estradiol.

free $\mathrm{T}$ and $\mathrm{T}$ bound to albumin-in other words the $\mathrm{T}$ not bound to Sex Hormone Binding Globulin (SHBG)-represent the bioavailable $\mathrm{T}^{11}$. Vice versa $\mathrm{T}$ bound to SHBG is not promptly available for binding the androgen receptor due to the high strength of the binding; this represents the amount of circulating $\mathrm{T}$ which is not bioavailable. ${ }^{7,11-14}$ Since bioavailable serum $\mathrm{T}$ is more available to the cells compare with SHBGbound serum $\mathrm{T}$, information on changes in both serum free and bioavailable $\mathrm{T}$ during aging is of relevance. ${ }^{14}$ SHBG increases with advancing age of about $2.7 \%$ per year, ${ }^{4,15,16}$ and accounts for an even larger decline in serum bioavailable $\mathrm{T}$ ( 3 to $4 \%$ per year) compare with total $\mathrm{T}$ in the elderly man. ${ }^{5}$ In addition, several factors (e.g. obesity $)^{17-20}$ and/or comorbidities, ${ }^{21,22}$ which become common with advancing age, might modify in percentage amount amount of different $\mathrm{T}$ fractions. ${ }^{7}$

Several methods are available to measure the different fractions of circulating $\mathrm{T}$. Total serum $\mathrm{T}$ is the fraction most commonly measured in clinical practice and is usually assayed with Immunoassays (IAs) in clinical laboratories. ${ }^{12,23-25}$ Mass spectrometry (MS), particularly liquid chromatography-tandem mass spectrometry (LC-MS/ MS), ${ }^{26}$ is considered the gold standard for the measurement of total serum $\mathrm{T}$, but, at present, is mainly used for research purposes. ${ }^{23,27}$ In general, results obtained with IAs do not reproduce in a reliable way those obtained with LC-MS/MS ${ }^{28}$ leading to the concept that commercially available IAs are widely inaccurate if compared with the gold standard. ${ }^{24,27-30}$ Accordingly, LC-MS/MS is able to lessen interferences, has better specificity, and reduce between-method bias. ${ }^{31}$ However, different results obtained by using different IAs are unimportant in the male, eugonadal range, but becomes relevant when measuring $\mathrm{T}$ levels falling in the low male range. ${ }^{23,27}$ In discordance with other studies, ${ }^{27}$ the comparison between serum total $\mathrm{T}$ measurements by using IAs or MS, which represents the gold standard for T levels measurement, has shown similar, highly-correlated results in the EMAS cohort. ${ }^{32}$ This means that IAs could be considered a good method for the evaluation of total serum $\mathrm{T}$ in clinical practice also for distinguishing between eugonadism and hypogonadism in the clinical setting. ${ }^{32}$ This issue is crucial for the diagnosis of male hypogonadism and is still controversial (see the paragraph below on the diagnosis of male hypogonadism in aging). In general, for clinical purposes it is important to validate the assay and to perform continuous quality control, independently from the methodology used. ${ }^{23,29,30,33}$ Furthermore, in the last few years, LC-MS/ MS is becoming more and more available in the clinical setting and this evolving scenario is expected to be implemented, especially in clinical laboratories able to provide high throughput outcomes thanks to the procedural low costs that allows saving money for each assay and writing off expenses due to initial purchase of technological equipments. ${ }^{23}$

The measurement of free serum $\mathrm{T}$ might be performed by means of equilibrium dialysis or ultrafiltration methods, which are, however, not manageable in clinical practice or, alternatively, by the use of direct free $\mathrm{T}$ assays, which are unreliable and strongly inaccurate. ${ }^{23,24}$ The better way to have an esteem of free serum $\mathrm{T}$ is to calculate free serum $\mathrm{T}$ starting from the value of total serum $\mathrm{T}$ and the measurement of both SHBG and albumin. ${ }^{7,13,23,24}$ Even though it is well known that calculated free $\mathrm{T}$ overestimates the value obtained by equilibrium dialysis, ${ }^{14}$ it remains largely employed both for research and clinical purposes.

Techniques for the measurement of bioavailable serum $\mathrm{T}$ are based on previous precipipation and separation of SHBG-bound T. For this reason, these methods are not simple and are not routinely employed in clinical laboratories. In addition, it is not clear the advantage of measuring bioavailable $\mathrm{T}$ rather than free $\mathrm{T}^{23}$. Starting from available data of serum albumin, SHBG, and total $\mathrm{T}$, it is possible to calculate free and bioavailable serum $\mathrm{T}$ by using a simple formula and a calculator widely available on the web (http://www.issam.ch/freetesto.htm). By taking into account all the issues mentioned before, it becomes clear that the comparison of the results coming from different studies suffers from bias due to methodological differences when measuring serum $\mathrm{T}$ and its decline during aging.

As serum $\mathrm{T}$ varies during the day ${ }^{34}$ and seasonally, ${ }^{25,35,36}$ it should be assayed in the morning and low 
values need to be confirmed twice in 2 different serum samples, the second one being obtained at least after 2 to 4 weeks after first $\mathrm{T}$ determination. ${ }^{12,25}$ Differences in timing serum samples for $\mathrm{T}$ determination might also account for discrepant results obtained in different research settings.

In addition, the decline of both total and free serum $\mathrm{T}$ shows of course a high degree of interindividual variability $^{5}$ accounting for serum $\mathrm{T}$ within the normal range in most of the elderly patients ( $>60$ years) and below the normal range in about $20 \%$ of them. ${ }^{37}$

Several risk factors have been associated with serum $T$ decline. ${ }^{38-40}$ Among them ethnicity, age, anthropometry, lifestyle factors, other concomitant comorbidities, chronic diseases, critical acute illnesses, drugs and/or other treatments should be taken into account. ${ }^{15,41}$ The main risk factors or clinical conditions associated with low serum $\mathrm{T}$ are listed in Table 1.

\section{Relationship between $T$ decline and estradiol $E_{2}$}

Longitudinal studies have shown that serum $\mathrm{E}_{2}$ declines in parallel with serum $\mathrm{T}$ in men., ${ }^{3,32,37}$ It is well known that serum $E_{2}$ rather than $T$ is important for bone health. ${ }^{42}$ Thus, the decline of serum $\mathrm{T}$ in older men becomes particularly harmful for the bone only when also serum $\mathrm{E}_{2}$ decreases. In particular serum $\mathrm{E}_{2}$ should decrease below a threshold which is in-between 15 and $25 \mathrm{pg} / \mathrm{mL}$ (55.1-91.8 pmol/L). ${ }^{42,43}$

Apart from the role of $\mathrm{E}_{2}$ on bone, other several physiological functions have been attributed mainly to $E_{2}$. Among them, the inhibitory effect of $\mathrm{T}$ on the hypothalamus and the pituitary seems to be due to a greater extent to its conversion into estrogens. ${ }^{44,45}$ Furthermore, also sexual function, especially sexual desire, is in part dependent from $\mathrm{E}_{2}$ too. ${ }^{45,46}$ Accordingly, serum $\mathrm{E}_{2}$ is directly related to sexual desire in men. ${ }^{47}$

Table 1. Risk factors involved in serum T decline in aging men.

\begin{tabular}{l}
\hline Risk factors and predictors of T deficiency: \\
General factors: Age, ethnicity, poor health status and frailty, progressive \\
decrease of number and function of Leydig cells. \\
Metabolic and and anthropometric factors: BMI, weight, waist \\
circumference, visceral adiposity. \\
Life-style habits: excessive alcohol intake, cigarette smoking, sedentary \\
lifestyle. \\
Comorbidities: hypertension, metabolic syndrome. \\
Chronic Diseases: moderate to severe chronic obstructive pulmonary disease, \\
HIV, chronic liver diseases, chronic renal failure (especially end-stage and \\
hemodyalisis), type 2 diabetes, hypopituitarism, reumatoid arthritis, \\
Hodgkin disease. \\
Critical Acute illness \\
Pharmacological and other treatments: opiates, glucocorticoids, inhibitors \\
of T synthesis (e.g., mitotane, ketoconazole), chemotherapy, testicular \\
irradiation, GnRH analogs
\end{tabular}

Note. T: testosterone; BMI: body mass index; GnRH: gonadotropin-releasing hormone.
At present less is known about the $\mathrm{E}_{2}$ interindividual differences in serum among men with hypogonadism. However, it is possible to hypothesize that hypogonadal men with a higher aromatase activity might be protected from the decrease of $\mathrm{E}_{2}$ when their serum $\mathrm{T}$ declines. ${ }^{48}$ $\mathrm{E}_{2}$ plays an important role also in the relationship between hypogonadism and obesity since the increased production of estrogens within the fat tissue contributes to inhibit luteinizing hormone (LH) secretion from the pituitary and to reduce $\mathrm{T}$ secretion from the testes. ${ }^{49}$ This mechanism could be involved not only in older men with hypogonadism, but also in other clinical conditions characterized by fat redistribution (e.g., Human Immunodeficiency Virus [HIV] infection). ${ }^{50}$

The measurement of serum $\mathrm{E}_{2}$, however, is not useful in clinical practice since the accuracy of IAs commonly used in the clinical laboratories is poor for the low values typical of the male range. ${ }^{51}$

\section{Age-related male hypogonadism: Results from large cohorts studies involving middle-aged to older men}

One of the first studies investigating serum $\mathrm{T}$ in aging men by a longitudinal design was the New Mexico Process Study ${ }^{52}$ that followed preliminary data previously obtained by cross-sectional studies. ${ }^{53-56}$ Previous data were contradictory and came from observational studies mainly based on inpatients with a poor health status, thus they were not representative on average of an aging population of men. ${ }^{37,54,57}$ After the above mentioned study, several other studies on large cohort of aging men were prospectively performed. Of them, the main are: the Baltimore Longitudinal Study of Aging (BLSA), the Massachusetts Male Aging Study (MMAS), the Osteoporotic Fractures in Men Study (MrOS), the European Male Aging Study (EMAS), the Rancho Bernardo Study (RBS), the InCHIANTI Study, the Tromsø Study, the Concord Health and Aging in Men Project (CHAMP), the Health in Men Study (HIMS). The main characteristics of these studies are all summarized in Table 2. All these studies differ each other for several aspects, including the main aim of the study (that not always is specifically addressed to the study of sex hormones decline during aging), the involvement of subjects of both genders, the duration of the study, and the number of participants (Table 2). As expected, also the methodological approach differ among studies both in terms of methods used for the assessment of circulating sex steroids, the type of sex steroid assayed (estradiol is not available from all the studies), the study design, and the clinical investigations included in the study protocol, the latter varying widely among studies according to their primary and secondary endpoints (Table 3, Table 4). Even though 
Table 2. Main characteristics of large cohort studies investigating sex steroids and aging.

\begin{tabular}{|c|c|c|c|c|c|c|c|c|c|c|}
\hline Study & $\begin{array}{l}\text { Period } \\
\text { (yrs) }\end{array}$ & $\begin{array}{l}\text { Study } \\
\text { Design }\end{array}$ & $\begin{array}{l}\text { Sex } M, \\
F\end{array}$ & $\begin{array}{l}\text { Subjects } \\
(\mathrm{N})^{*}\end{array}$ & Age & $\begin{array}{l}\text { Span } \\
\text { (yrs) }\end{array}$ & T assay** & $\begin{array}{l}\text { Sex Steroids } \\
\text { as Main Aim }\end{array}$ & Primary End Point ${ }^{\wedge}$ & Country \\
\hline BLSA & 1958- & PLOC-B & $M, F$ & n.a. & $>20$ & 58 & IAs & no & $\begin{array}{l}\text { General overview on } \\
\text { aging }\end{array}$ & Baltimore (USA) \\
\hline MMAS & 1987-2004 & PLOC-B & M & 1709 & $40-70$ & 17 & IAs & yes & Hormone levels and ED & Boston (USA) \\
\hline MrOS & 2000-2006 & $\begin{array}{l}\text { MC-PLOC- } \\
\text { B }\end{array}$ & M & $\sim 11000$ & $>65$ & 6 & LC-MS/MS & no & Fracture risk factors & $\begin{array}{l}\text { USA, Sweden, Hong- } \\
\text { Kong }\end{array}$ \\
\hline EMAS & 2003-2010 & $\begin{array}{l}\text { MC-PLOC- } \\
\text { B }\end{array}$ & M & 3369 & $40-79$ & 7 & $\begin{array}{l}\text { LC-MS/MS } \\
\text { IAs }\end{array}$ & yes & $\begin{array}{l}\text { Anabolic hormones } \\
\text { changes and health } \\
\text { outcomes }\end{array}$ & Some EU Countries \\
\hline RBS & 1972- & PLOC-B & $M, F$ & 1094 & $>30$ & 44 & IAs & no & Heart disease risk factors & $\begin{array}{l}\text { Southern California } \\
\text { (USA) }\end{array}$ \\
\hline InCHIANTI & 1998- & PLOC-B & $\mathrm{M}, \mathrm{F}$ & 601 & $>65$ & 18 & IAs & no & Physical function in aging & Tuscany (Italy) \\
\hline Tromsø & 1974-2008 & PLOC-B & $M, F$ & 6595 & n.d. & 34 & IAs & no & CV-related mortality & Tromsø (Norway) \\
\hline CHAMP & 2005- & PLOC-B & M & 1705 & $>70$ & 11 & LC-MS/MS & no & Major geriatric syndromes & Sydney (Australia) \\
\hline HIMS & 1996-2004 & P-BRT & M & 12203 & $>65$ & 8 & IAs & no & Aortic aneurysm in aging & Perth (Australia) \\
\hline
\end{tabular}

Notes. M: males; F: females; ${ }^{*}$ Number of male participants at the beginning of the study; ${ }^{* *}$ For some studies methods for T assay varied overtime during the long period of study protocol; ^UK, Italy, Belgium, Poland, Sweden, Spain, Hungary, Estonia; EU: European; ${ }^{\wedge}$ The main end point to be investigated in relation to aging; PLOC-B: Prospective, Longitudinal, Observational, Community-Based Study; MC-PLOC-B: MultiCenter, Prospective, Longitudinal, Observational, Community-Based Study; P-BRT: Population-Based, Randomized, Trial; n.d.: not detectable at any analysis; CV: cardiovascular; ED: erectile dysfunction.

the comparison among all these studies goes beyond the aim of this review, we will try to report in a critical fashion the aspects that are more relevant for the comprehension of the relationship between sex hormones and aging in males.

\section{Main characteristics of large cohort studies}

The BLSA is a longitudinal study on human aging, which begun in 1958 (https://www.blsa.nih.gov/about/history/); it is the oldest study taking into account sex steroids changes during aging in men and is based on enrollment of participants with different ages who are followed afterward all lifelong. ${ }^{58}$ This is one of the biggest studies on aging showing $\mathrm{T}$ levels decline in men and its relationship with several aspects related to aging ${ }^{4}$ (Table 2). Other than BLSA, also the RBS and the Tromsø Study are very old, being started in the 70s (Table 2). ${ }^{59,60}$

Among studies that have specifically investigated the decline of sex steroids, particularly $\mathrm{T}$, in middle-aged to older men, the MMAS is one of the pioneering study, the investigation of sex hormones changes in aging being the main study endpoint (Table 2). ${ }^{53,61}$ The MrOS study is a multicenter study enrolling around 6000 men older than $65 \mathrm{y}$ in order to identify risk factors for fractures in older men (Table 2). ${ }^{62}$ By enrolling men also from Sweden and Hong Kong, the study has reached a considerable number of participants (Table 2). The main aim of the study, however, was to evaluate the association between sex hormones levels and osteoporosis rather than overtime changes during aging (Table 2). ${ }^{62}$

The EMAS (http://www.emas.man.ac.uk) is a multicenter (involving 8 European centers) cohort study that has been pointedly designed in order to evaluate physical, psychological and endocrine changes overtime, with particular attention to modifications of $\mathrm{T}$ secretion occurring with aging. ${ }^{63,64}$ (Table 2).

The Rancho Bernardo Study started as a survey of heart disease risk factors in adults who were older than $30 \mathrm{y}$ and lived in the southern California community of Rancho Bernardo, that has progressively accumulated a lot of data (not only on CV system) from this cohort across the last 40 years $^{59,65}$ (Table 2).

The InCHIANTI study involves older people living in the Chianti geographic area (Tuscany, Italy) (http://inchian tistudy.net/wp/). For the majority of men, measurements of total T, $\mathrm{E}_{2}$ and SHBG serum levels were available, even though the main aim of the study was not strictly related to hormonal changes overtime ${ }^{66-70}$ (Table 2).

The Tromsø study (https://en.uit.no/prosjekter/ prosjekt?p_document_id=80172) is composed by several surveys performed in sequence and collecting information that have changed overtime across different surveys ${ }^{60,71,72}$ The fourth survey was taken between 1994 and 1995; all inhabitants of Tromsø (Northern Norway) older than $24 \mathrm{y}$ were invited and, between the subjects who accepted to take part to the study, all men aged 55-74 y and random samples of the other age groups were involved and hormonal measurements performed ${ }^{60}$ (Table 2).

The CHAMP study was originally designed in order to investigate the health status in men older than $70 \mathrm{y}$ living in a defined geographical region near the Concord Hospital in Sydney. ${ }^{73-75}$ The study paid particular attention to the effects of age-related sex hormones decline. ${ }^{73}$ After a baseline assessment; a subsequent, biennial follow up was then realized. ${ }^{73} \mathrm{~A}$ strength of this project is the use of LC-MS/MS for steroid assays, which represents currently the "gold standard"(Table 2). ${ }^{74,76,77}$ The HIMS (https://www.perkins.org.au/wacha/our-research/mens/ 
VIRULENCE

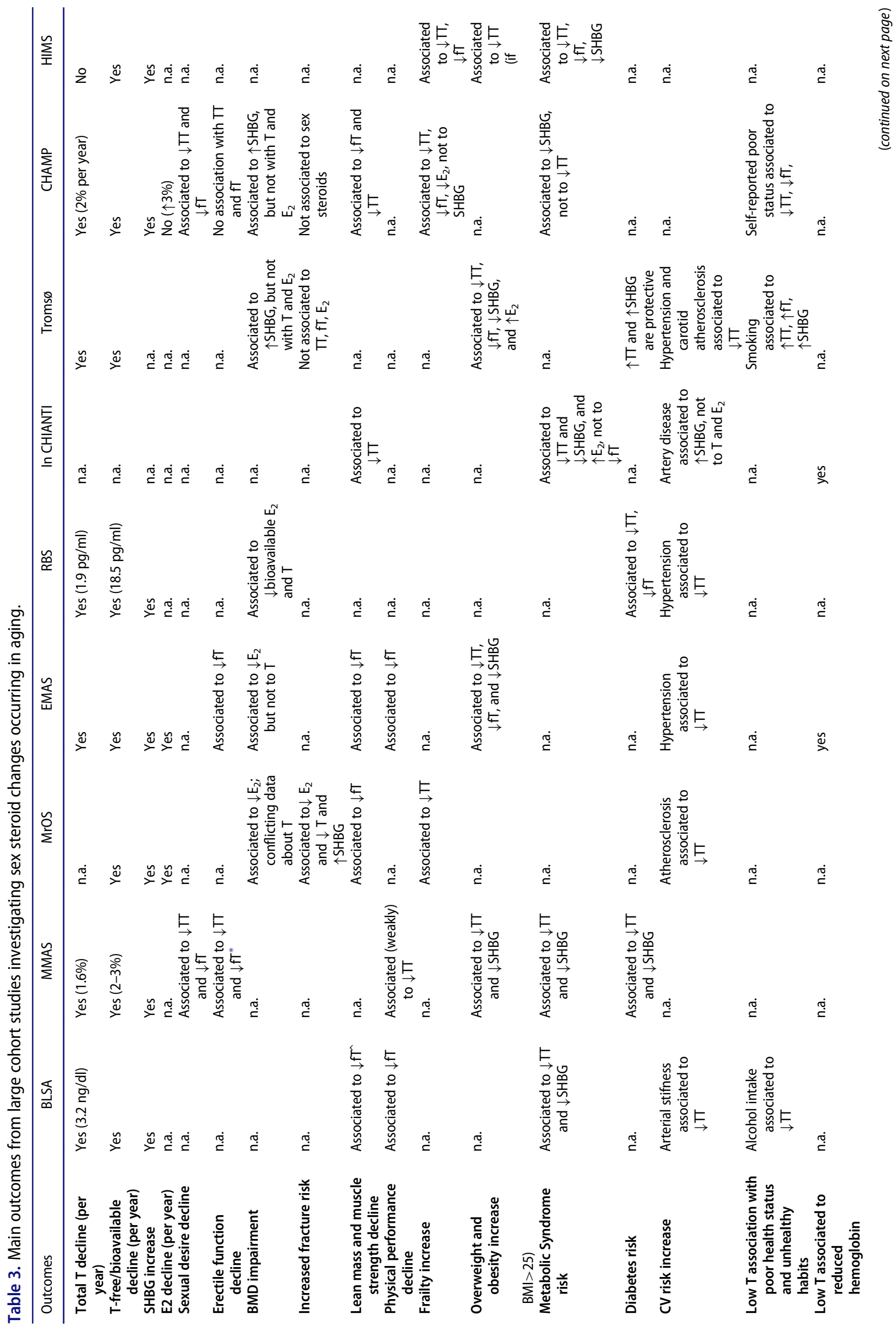




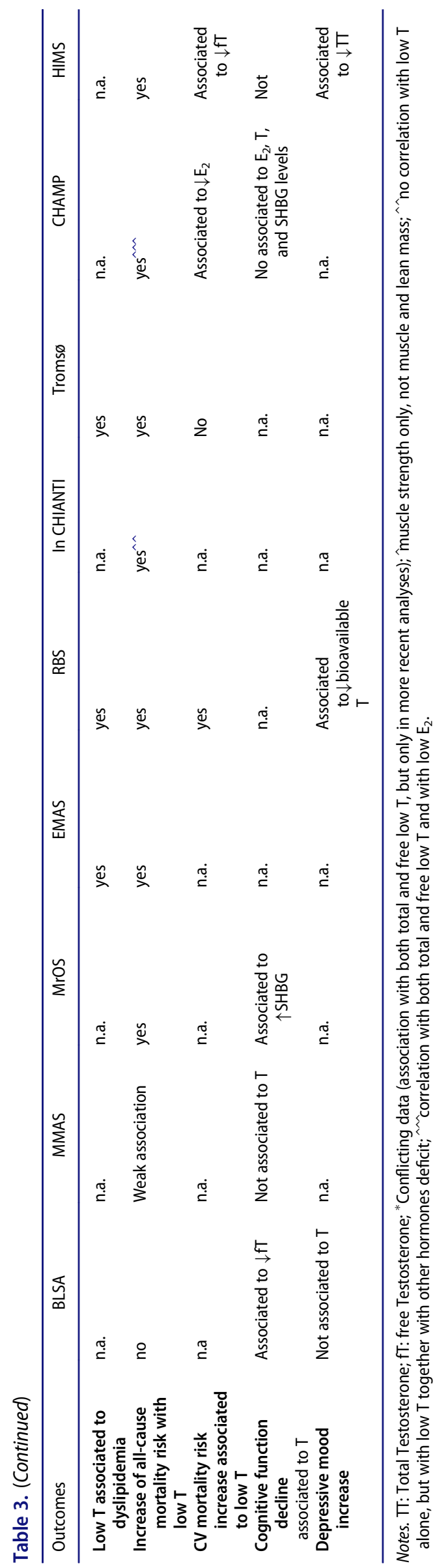


Table 4. Main similarities and differences of large longitudinal, cohort studies.

\begin{tabular}{|c|c|c|c|}
\hline STRONG DISCREPANCIES & WEAK DISCREPANCIES & WEAK ANALOGIES & STRONG ANALOGIES \\
\hline \multicolumn{4}{|c|}{ Hormonal Trajectories } \\
\hline- & - & $\begin{array}{c}\downarrow \text { serum total and free } E_{2} \\
\text { with advancing age }\end{array}$ & $\begin{array}{c}\downarrow \text { serum total T } \\
\downarrow \downarrow \text { serum free T } \\
\downarrow \downarrow \text { bioavailable T } \\
\uparrow \text { serum SHBG } \\
\text { with advancing age }\end{array}$ \\
\hline \multicolumn{4}{|c|}{ Consequences of Hormonal Changes Related to Male Aging } \\
\hline $\begin{array}{l}\text { - Association between low T } \\
\text { and low BMD. } \\
\text { - Association between low T } \\
\text { and depression. } \\
\text { - Association between low T } \\
\text { and CV-related mortality. } \\
\text { - Relationship between T and } \\
\text { physical performance. } \\
\text { - Relationship between T and } \\
\text { prostate cancer. }\end{array}$ & $\begin{array}{l}\text { - Association between T and cognitive } \\
\text { functions. } \\
\text { - Association between low T and } \\
\text { atherosclerosis. } \\
\text { - Relationship between hypogonadism } \\
\text { and frailty development. } \\
\text { - Correlation between serum T } \\
\text { measured by LC-MS/MS and by Als. } \\
\text { - Association between low T and } \\
\text { impaired pulmonary function. } \\
\text { - Association between low T and/or } \\
\text { low } \mathrm{E}_{2} \text { and frailty. }\end{array}$ & $\begin{array}{l}\text { - Association between low T and CV } \\
\text { risk factors' increase. } \\
\text { - Association between low T and } \\
\text { increased CV risk. } \\
\text { - Association between low T and poor } \\
\text { health status. } \\
\text { - Association between low T and low } \\
\text { hemoglobin. } \\
\text { - High T correlates with better lean } \\
\text { mass, and muscle strength. } \\
\text { - Low T correlates with erectile } \\
\text { dysfunction. } \\
\text { - Serum } \mathrm{E}_{2} \text { is inversely related to } \\
\text { fracture risk. }\end{array}$ & $\begin{array}{l}\text { - Serum T is directly related to sexual } \\
\text { function, especially libido. } \\
\text { - Association between low T and } \\
\text { increased all-causes mortality risk. } \\
\text { - Healthy life-style correlates with } \\
\text { higher T levels/prevention of T } \\
\text { decline. } \\
\text { - Association between low T and } \\
\text { both overweight and obesity. } \\
\text { - Association between low T and } \\
\text { both metabolic syndrome and } \\
\text { type } 2 \text { diabetes. } \\
\text { - Serum } \mathrm{E}_{2} \text { correlates with BMD. }\end{array}$ \\
\hline
\end{tabular}

mens-health-1/) was initially realized as a trial of screening for abdominal aortic aneurysms in Perth, Australia, but blood samples were obtained since baseline from all participants, thus it was possible to correlate their gonadal status to different physical, metabolic and psychological aspects. ${ }^{78}$ However, the study was not addressed specifically to reach endocrinological endpoints $^{78}$ (Table 2).

\section{Age-related sex steroids changes across cohort studies}

Almost all the studies found a decline of total serum $\mathrm{T}$ with advancing age (Table 3, Table 4). The BLSA estimated a decline of total serum $\mathrm{T}$ around $3.2 \mathrm{ng} / \mathrm{dl}$ per year, ${ }^{4,79}$ this esteem being around $1.9 \mathrm{pg} / \mathrm{ml}$ per year in the RBS, ${ }^{80}$ while the first data coming from the MMAS reported a decline of serum total and free $\mathrm{T}$ of about $0.4 \%$ and $1.2 \%$ per year, respectively ${ }^{53}$ (Table 3 ). More recently, the CHAMP study showed a decline of serum total $\mathrm{T}$ around $2 \%$ per year $^{81}$ (Table 3 ).

The EMAS results have confirmed, in the last years, the data concerning the progressive decline in aging men of serum total $\mathrm{T}$, free $\mathrm{T}$, and $\mathrm{E}_{2}{ }^{82}$, as well as those concerning the rise of SHBG with aging ${ }^{83}$ (Table 3 ).

The CHAMP recently replicated these results except for a surprising increase of $\mathrm{E}_{2}{ }^{81}$ (Table 3).

In the HIMS study, serum free $\mathrm{T}$ significantly decreased with increasing age, while total serum $\mathrm{T}$ levels seemed to remain stable; this is probably due to the important increase of SHBG in older age, which could justify the persistence of stable total T levels ${ }^{84}$ (Table 3 ).

In line with other studies, also the RBS showed a decline of both total and bioavailable serum $\mathrm{T}$ levels with aging $^{80}$ (Table 3). In particular, bioavailable serum T levels decreased more $(18.5 \mathrm{pg} / \mathrm{ml})$ than serum total $\mathrm{T}$ in aging men mainly due to the corresponding increase of SHBG with age, ${ }^{59,80,85}$ (Table 3).

Even though the MrOS did not provide data on the trajectories of sex steroids overtime, it indirectly has confirmed that both serum $\mathrm{T}$ and $\mathrm{E}_{2}$ decline with advancing age $^{86,87}$ (Table 3). By dividing participants according to quartiles of SHBG and sex steroids, in fact, their age was higher in the higher quartiles of serum $\mathrm{SHBG}^{88}$ and in the lower quartiles of both serum $\mathrm{E}_{2}{ }^{86}$ and free $\mathrm{T}^{87}$.

Vice versa no data on the decline of sex steroids were available in the InChianti study even though measurements of total T, $\mathrm{E}_{2}$ and SHBG serum levels were available for the majority of men ${ }^{67,70,85}$ in this study hormonal data were mainly used for investigating the association between circulating sex steroids and several conditions that are common in aging ${ }^{69,68,67,70,66}$ (Table 3 ).

\section{Male hypogonadism across cohort studies}

The prevalence of biochemical hypogonadism seems always to increase with advancing age, being independently from the study considered, at the lowest in men younger than $49 \mathrm{y}$ and progressively increasing through decades, with the highest prevalence being in men in 
their 80 s. $^{4,8,82,83,89,90}$ However, according to a more recent analysis, total serum $\mathrm{T}$ levels seem to be quite stable until the age of 70 years, after that there would be a progressive, significant decline, while the bioavailable serum $\mathrm{T}$ seems to decline more linearly with aging. ${ }^{79}$

In line with other studies, ${ }^{3,8,89,90}$ in the Tromsø study the investigation of hormonal changes with aging resulted in the finding of lower serum $\mathrm{T}$ levels and higher gonadotropins levels in older men $^{60}$ (Table 3), even though the measurement of gonadotropins in aging men is scarcely helpful in predicting the future development of hypogonadism $^{91}$ (Table 3).

Several cutoffs for male hypogonadism have been suggested on the basis of the results of these large cohort studies. The MMAS study has suggested the following age-related cutoffs for serum total T: $251,216,196$, and $156 \mathrm{ng} / \mathrm{dL}(8.7,7.5,6.8$, and $5.4 \mathrm{nmol} / \mathrm{L})$ for men in their 40 s, 50s, 60, and 70s, respectively. ${ }^{61}$ Many data about aging and gonadal status arose from the EMAS and the identification and definition of the $\mathrm{LOH}$ as a clinical condition has been one of the biggest results. ${ }^{3} \mathrm{LOH}$ has been in fact defined as a condition characterized by 3 sexual symptoms (decreased sexual thoughts, decreased frequency of morning erections and erectile dysfunction) together with total serum $\mathrm{T}$ less than $317 \mathrm{ng} / \mathrm{dL}(11 \mathrm{nml} /$ $\mathrm{L})$ and free $\mathrm{T}$ less than $63,4 \mathrm{pg} / \mathrm{mL}(220 \mathrm{pmol} / \mathrm{L}){ }^{3}$ According to the grade of serum $\mathrm{T}$ decrease, $\mathrm{LOH}$ can be considered as moderate or severe. In particular, total serum $\mathrm{T}$ concentrations lower than or equal to $230 \mathrm{ng} /$ $\mathrm{dL}(8 \mathrm{nmol} / \mathrm{L})$ have been associated with worse sexual functioning and higher rates of erectile dysfunction. ${ }^{92}$

\section{Main outcomes of cohort studies}

The comparison of such kind of large cohort studies clearly remarks the great heterogeneity of outcomes, which differ for each study according to the peculiarity of the study design and the number and type of clinical and laboratory data collected. While data on trajectories of sex steroids are almost available in all studies (see the paragraph above), information about the relationships among circulating sex steroids and/or various clinical aspects and physiological changes related to aging become patchy when moving across the various studies (Table 3).

While changes in circulating total, free, and bioavailable $\mathrm{T}, \mathrm{E}_{2}$, and SHBG are unidirectional in almost all the studies, several other outcomes were not replicated, thus leading to conflicting results when different studies are compared each other (Table 3, Table 4).

The relationship between the decline of serum $\mathrm{T}$ and the worsening of sexual function has been investigated and confirmed by most of these studies (Table 3). The MMAS, ${ }^{93,94}$ the CHAMP, ${ }^{74}$ and the EMAS. ${ }^{3,95}$ provided a lot of data on the relationship between gonadal status and sexual desire, sexual function, and erectile function in middle-aged to older men (Table 3), suggesting that loss of sexual desire, but not erectile function, is strictly related to low $\mathrm{T}$ in aging men ${ }^{96}$ and could be predictive for the development of erectile dysfunction (ED) ${ }^{94}$ Thus, low serum $\mathrm{T}$ (the main component of low desire) is indirectly related to the onset of $\mathrm{ED}$ and to impaired male sexual function. ${ }^{47}$ In particular, in the EMAS study lower serum free $\mathrm{T}$ levels have been more strongly associated with severe sexual dysfunction (such as increased erectile dysfunction and lower masturbation frequency). ${ }^{83,92}$ Less data are available on sexual function in the BLSA and MrOS studies ${ }^{97}$ (Table 3).

Overweight and obesity are strongly associated to the decline of both total serum T and SHBG in several studies such as the MMAS, ${ }^{37,98,99}$ the BLSA, ${ }^{4}$ the EMAS, ${ }^{100}$ and the Tromsø, ${ }^{101,102,103}$ studies (Table 3). Changes in body composition lead to an increased risk of developing both the metabolic syndrome ${ }^{104}$ dyslipidemia, ${ }^{65,105,106}$ and diabetes ${ }^{107}$ (Table 3).

Metabolic syndrome was associated to low serum $\mathrm{T}$ and/ or low SHBG in the BLSA, ${ }^{41}$ HIMS, ${ }^{108,109}$ InChianti, ${ }^{68,67}$ Tromsø, ${ }^{110,111,112}$ and RBS. ${ }^{65,105,106}$ studies, but not in the CHAMP study, the latter showing an association between lower SHBG levels, but not $\mathrm{T}$, and the development of metabolic syndrome ${ }^{76}$ (Table 3 ).

The EMAS study showed that weight loss is associated to an increase, while weight gain to a decrease in both total and free serum $\mathrm{T}$, with the same association persisting by considering waist circumference ${ }^{82}$ As previously reported, obesity probably determines an impairment of the hypothalamic-pituitary function, leading to lower LH incretion and finally to hypogonadotropic hypogonadism. This evidence is very important because it suggests that weight management and obesity avoidance could be useful to prevent $\mathrm{T}$ decline. ${ }^{82,100}$ Furthermore, the relationship between weight and $\mathrm{T}$ is probably bidirectional, since hypogonadism promotes fat accumulation and low total and free serum $\mathrm{T}$ levels have been associated with an increased risk of developing metabolic syndrome. ${ }^{18}$

Data on the relationship between $\mathrm{T}$ and the cardiovascular (CV) system are available from the BLSA, ${ }^{113}$ the MrOS,${ }^{114}$ the Troms $\varnothing,{ }^{110,111,112}$ and the RBS, ${ }^{115}$ showing that hypertension is associated to low serum $\mathrm{T}$ (Table 3 ). As suggested by the Tromsø study, smoking, overweight, and obesity represent possible confounding factors when evaluating the relationship between serum $\mathrm{T}$ and $\mathrm{CV}$ diseases in cohort studies. ${ }^{116}$

The major role of serum estrogens on bone health has been suggested by almost all the studies, ${ }^{117}$ serum $\mathrm{E}_{2}$ and $\mathrm{T}$ being directly correlated with bone mineral density (BMD). This correlation is particularly strong for free 
serum $\mathrm{E}_{2}{ }^{86,118,119}$. Furthermore, the MrOS has shown that low serum $\mathrm{T}$ together with high SHBG levels and low serum estradiol levels are associated with increased risk of non-vertebral fracture. ${ }^{117}$ On the other hand, data about the effects of serum $\mathrm{T}$ on BMD remain conflicting since the association between low serum $\mathrm{T}$ and lower BMD has not been demonstrated in all studies, such as the MrOS. ${ }^{120}$ In the EMAS study, however, men with overt hypogonadism (total $\mathrm{T}<230 \mathrm{ng} / \mathrm{dL}[8 \mathrm{nml} / \mathrm{L}]$ ) show worse serum parameters of bone health compared with eugonadal men. ${ }^{18,121}$ Probably, $\mathrm{T}$ contributes to bone health through its effect on muscle mass (and the consequent mechanical load on bone) and via aromatization to estrogens. ${ }^{42,48,121}$ Thus, low circulating levels of $\mathrm{T}$ result in parallel in low serum $\mathrm{E}_{2}{ }^{42,48}$. Differently from the majority of studies, the CHAMP study did not find any association among serum T, E2, SHBG, and bone health, ${ }^{122}$ on one hand, and, on the other hand, the Tromsø did not find any association between sex steroids and both $\mathrm{BMD}^{71}$ and fracture risk. ${ }^{72}$

Low total $\mathrm{T}$ levels were associated with lower hemoglobin levels in the InCHianti study similarly to EMAS, ${ }^{89}$ suggesting that the effects of low $\mathrm{T}$ on hemoglobin should be carefully evaluated in older men due to the fact that anemia is one of the strongest markers of frailty $^{69}$

Not all studies investigated physical performance and both the muscular mass and strength in relation to circulating sex steroids. ${ }^{77,123,124}$ (Table 3). Physical performance was only weakly associated to serum $\mathrm{T}$ in the MMAS $^{125}$ In regard to body composition, total serum T is related directly to lean mass, playing a possible protective role in healthy aging, since a better muscular function helps preventing falls, fractures, and frailty to some extent, as suggested by the MrOS study. ${ }^{126}$

Low total and free serum T levels have been also associated with frailty in the HIMS, ${ }^{127}$ CHAMP, ${ }^{128}$ and the MrOS studies. ${ }^{129}$ In addition, men with poor health status, in particular those who had a stroke or a cancer diagnosis, had lower levels of both total and free serum $\mathrm{T}$ levels in the Tromsø study, ${ }^{91}$ while self reported worse health status was associated to low $\mathrm{T}$ in the $\mathrm{CHAMP}^{75}$ (Table 3). Otherwise, in the MMAS a good health and the absence of chronic illness were both associated with a less important decline of serum $\mathrm{T}^{37}$ (Table 3 ).

Not all the studies investigated neuropsychological correlates of age-related $\mathrm{T}$ decline. The BLSA studied the possible correlation between androgens and cognitive function leading to a possible role of $\mathrm{T}$ in preventing cognitive dysfunction and depressive mood. ${ }^{130-132}$ These data on $\operatorname{mood}^{105}$ and cognition were also replicated by the RBS study, ${ }^{133}$ and the HIMS ${ }^{134}$; in particular the latter showed an increased risk of developing depressive symptoms in association to low serum total $\mathrm{T}^{135}$ (Table 3). Conversely, no relationship between sex steroids and cognition was found in other studies, such as the MMAS, ${ }^{136}$ the CHAMP, ${ }^{137}$ and the MrOS. ${ }^{97}$

In these large cohort studies, low serum free $\mathrm{T}$ was almost constantly associated with an increased all-causes mortality risk, this association was found by the HIMS, ${ }^{138}$ CHAMP,${ }^{81}$ MMAS, ${ }^{139}$ EMAS, ${ }^{95}$ RBS, ${ }^{119}$ Tromsø, ${ }^{140}$ and $\mathrm{MrOS}^{141}$ studies. In the MrOS the mortality risk appeared to be higher when also low serum $\mathrm{E}_{2}$ was present. ${ }^{141}$ Vice versa, the InChianti study did not find any association between low baseline free serum $\mathrm{T}$ levels and 6-years mortality risk. ${ }^{66}$ The association between low serum $\mathrm{T}$ and mortality due to $\mathrm{CV}$ events remains less known since this association was proven only by the HIMS study. ${ }^{138}$

\section{Lesson learnt from large cohort studies}

The integrated analysis of data provided by these large longitudinal studies allows highlighting several issues that are of concern for research advancement, methodological outcome and finally for clinical practice.

At the beginning most of these longitudinal studies provided first analyses based on cross-sectional data. ${ }^{53,142}$ The longitudinal design of the studies came up progressively as the studies aged together with their participants. First cross-sectional data did not find changes in circulating sex steroids between older and younger participants. ${ }^{142}$ Subsequently, the decline of sex steroids was unequivocally proved when the data from longitudinal analyses became available. Accordingly, the most important result reached by all the studies is to demonstratethe serum $\mathrm{T}$ decline with advancing age. Particularly, both free and total serum $\mathrm{T}$ levels tend to decrease; the latter decreases lesser than the former as a consequence of the progressive increase of SHBG with aging (Table 4). Also the modification of SHBG has been confirmed by all the studies (Table 4 ).

In all studies that have investigated male sexuality, serum $\mathrm{T}$ resulted inversely related to sexual desire and to some extent to sexual activity and erectile function too (Table 4). Another concordant result is the association between low serum $\mathrm{T}$ and obesity, metabolic comorbidities such as the metabolic syndrome, and type 2 diabetes (Table 4).

Among other clinical aspects that are associated to serum $\mathrm{T}$ lowering with advancing age, all-cause mortality, body composition changes, especially overweight ad obesity as well as metabolis syndrome and diabetes, all have been over and over again associated to $\mathrm{T}$ decline in aging (Table 4).

The methodological approach used for $\mathrm{T}$ measurement has changed overtime according to advancements 
in this field in all the studies (Table 4). At present, the gold standard LC-MS/MS is being used in all studies, while at the beginning of the studies sex steroids were measured by IAs. This implies that the comparison of the results coming from different studies as well as the results of the same study obtained in different periods by using different assay methods remain challenging. There is not consensus about the correlation between total serum $\mathrm{T}$ measured by MS and IAs among studies since some studies find a good correlation while others find discordant measurements (Table 4). This issue is important when data coming from research studies like these are transposed and applied to daily clinical practice since IAs are commonly employed, at present, in clinical laboratories.

A lesser degree of certainty has been reached regarding the association between $\mathrm{T}$ lowering with advancing age and $\mathrm{CV}$ diseases, increse ìog $\mathrm{CV}$ risk, $\mathrm{ED}$, and impaired bone health (Table 4).

The most controversial issues concern the association of $\mathrm{T}$ decline to impaired physical performance, neuropsychological issues, CV-related mortality, and cancer risk (Table 4).

Table 4 summarizes in detail the main analogies and discrepancies regarding the issues that have been mostly investigated by large cohort studies till now (Table 4).

\section{Significance of age-related serum $T$ changes in aging men}

The decline of serum $\mathrm{T}$ with advancing age has been traditionally interpreted as the male counterpart of menopause. In other words, the decrease of $\mathrm{T}$ was considered as a condition due to the aging of gonadal function. In this old view, the term andropause was considered as a physiological event like menopause in females ${ }^{143-145}$ with the unique difference that the ovaries stop to function suddenly while the testes loose their function gradually (Fig. 1).

At present, it has not defined whether the decline of serum $\mathrm{T}$ in the elderly represents a physiological process of aging or whether this event should be considered as pathological. In 2004 Snyder stated that 'an essential but still unanswered question is whether this decrease in the testosterone concentration is physiologic, perhaps conveying a benefit, or pathologic, causing harm' ${ }^{146}$ Today, this point remains still crucial in order to establish if a strategy that is effective in counteracting serum $\mathrm{T}$ decline should be set up or if treating serum $\mathrm{T}$ decline maybe potentially harmful. With this in view, the identification of patients with low serum $\mathrm{T}$ that might beneficiate of replacement therapy on one hand and the recognition of those for which therapy is not indicated is challenging.
All these issues usually converge on the practical point concerning how to diagnose $\mathrm{LOH} .{ }^{147}$

\section{The clinical diagnosis of LOH: lights and shadows}

Recently, there is consensus among endocrinologists, andrologists, and urologists about the fact that the finding of biochemical $\mathrm{T}$ deficiency does not necessarily correspond to $\mathrm{LOH}$ in middle-aged-to-older men. ${ }^{12,25,38-40,49,147,148}$ Accordingly, lower serum $\mathrm{T}$ in older men should not be considered "per se" significant, but it acquires a clinical value in men with concomitant signs and symptoms of $\mathrm{T}$ deficiency, a condition known as hypogonadism. $3,12,25,38,40,49,148$ Some aspects related to the diagnosis of hypogonadism do not differ according to the patients' age (e.g., categories of hypogonadism), while for other aspects (e.g., causes of hypogonadism, signs and symptoms, and serum $\mathrm{T}$ thresholds) the patients' age does matter. ${ }^{40,49,149,150}$

\section{Classification of $\mathrm{LOH}$}

In general, 2 main forms of hypogonadism can be distinguished: (a) primary hypogonadism (or hypergonadotropic hypogonadism), where the site of origin is the testis and which is characterized by low T levels with high gonadotropins levels, and (b) secondary hypogonadism (or hypogonadotropic hypogonadism), in which there is hypothalamic and/or pituitary failure causing low gonadotropins production and consequent low T levels ${ }^{12,25,49,148}$ (Fig. 2). Furthermore, among aging men is quite common a condition of compensated hypogonadism, represented by normal $\mathrm{T}$ levels with high gonadotropins levels, whose prevalence increases with aging and which seems to be a subclinical condition that could develop in overt, primary hypogonadism overtime ${ }^{90}$ (Fig. 2). Recently, data coming from the EMAS study confirm that age is correlated with the development of primary hypogonadism, but not with secondary hypogonadism, the latter being strictly associated to comorbidities rather than age. $3,151,152$

\section{Causes of $\mathrm{LOH}$}

In younger men hypogonadism (both hypergonadotropic and hypogonadotropic) is usually due to wellknown causes, which can be congenital or acquired, and the site of origin is easily recognizable. ${ }^{40,49,149,150}$ Conversely, many different factors, some of which are still not well defined, contribute to the decrease of $\mathrm{T}$ production in aging men (Table 1). For example, aging "per se" is known to induce a progressive dysfunction of Leydig cells, but age-advanced typical chronic comorbidities (e.g., cancer, chronic obstructive pulmonary disease, chronic renal failure and chronic liver failure) are also associated with low serum $\mathrm{T}$ (Table 1). ${ }^{6,153}$ Accordingly, age and chronic diseases resulted associated to primary 


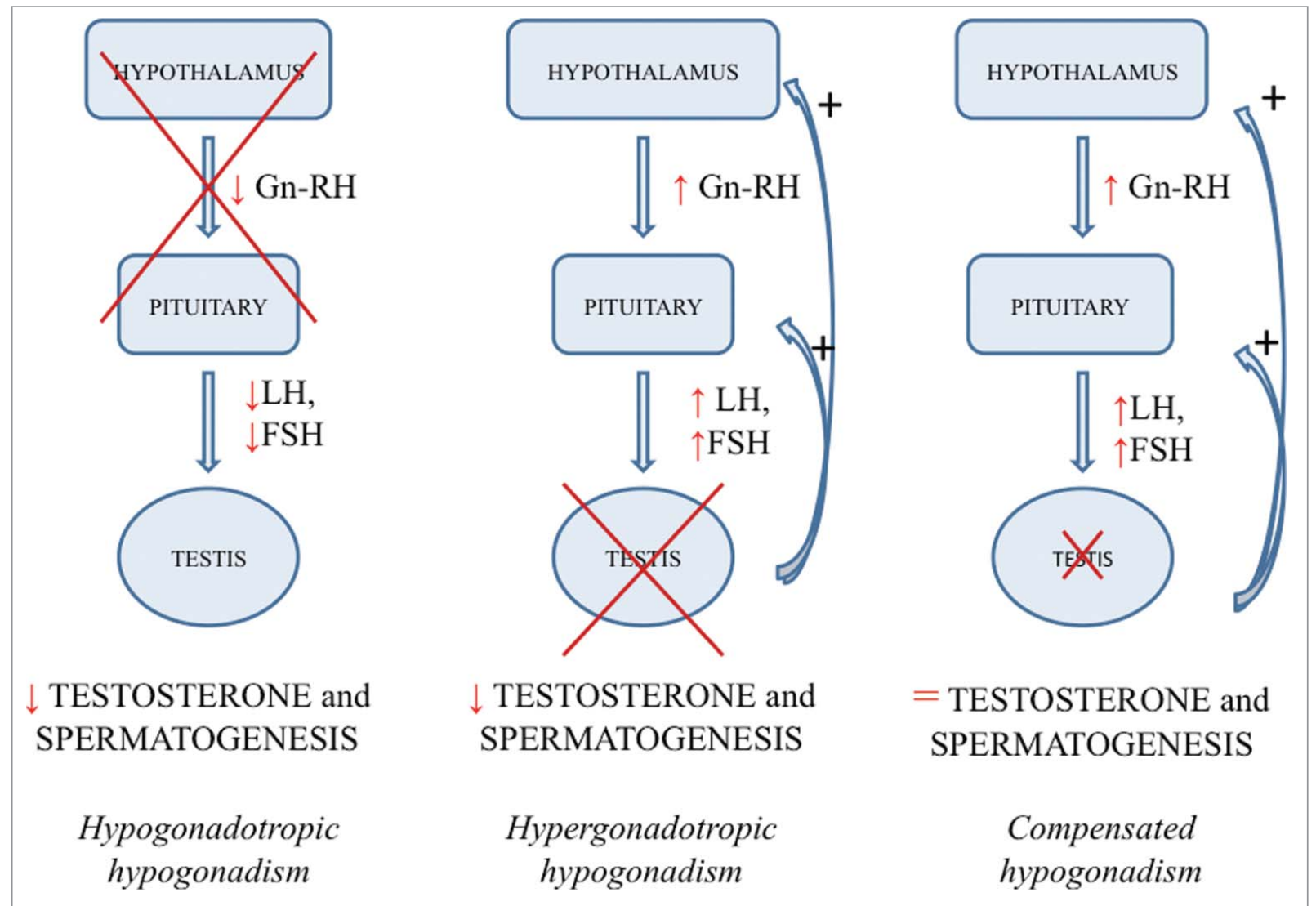

Figure 2. Classification of hypogonadism according to its pathogenesis.

hypogonadism in the EMAS cohort. ${ }^{151}$ Thus, low serum $\mathrm{T}$ of the elderly man is often due to both primary and secondary failure of $\mathrm{T}$ secretion. Other factors involved in serum $\mathrm{T}$ declining include bad lifestyle habits, such as smoking and excessive alcohol intake, and chronic therapies with opiates and glucocorticoids, increasingly used to treat elderly population (Table 1$)^{6}{ }^{6}$ Several clinical conditions (e.g., chronic or acute diseases) are associated to hypogonadism in aging men, some of them cause secondary hypogonadism, which is not related to age and might be reversible. ${ }^{15,152}$ In particular, diabetes mellitus, obesity and metabolic syndrome seem to play a major role especially in decreasing gonadotropin levels, leading to secondary hypogonadism (Table 1$) \cdot{ }^{90,147}$ Other factors involved in serum $\mathrm{T}$ declining include bad lifestyle habits, such as smoking and excessive alcohol intake, and chronic therapies with opiates and glucocorticoids, increasingly used to treat elderly population (Table 1$)^{6}$ Here we summarize the main clinical conditions and diseases linked to hypogonadism.

\section{Hypogonadism and non-infectious comorbidities}

Chronic non-infectious diseases. Hypogonadism might occur in several chronic conditions at any age, but it is self- evident that this association increases with advancing age as a consequence of higher probability to develop and/or accumulate new morbidities during aging. ${ }^{15,91,154}$

Overweight, obesity, and metabolic disorders (metabolic syndrome, diabetes, dyslipidemia) are more frequent in older men and are all associated to low serum $\mathrm{T}$ in men, as already discussed in this article. ${ }^{20,22,40,41,102,103,105,107,152}$

Chronic liver diseases, especially cirrhosis and fatty liver disease, ${ }^{155}$ are associated to hypogonadism as a consequence of increased liver production of SHBG and of estrogen excess and its inhibitory effect on gonadotropins. ${ }^{22}$

The prevalence of hypogonadism seems to be high in men with chronic obstructive pulmonary disease (COPD), especially in middle-aged and elderly men, ${ }^{22,153}$ ranging from 22 to $69 \% .{ }^{156,157}$ In particular, secondary hypogonadism is associated to COPD and the severity of COPD seems to be directly correlated with the degree of hypogonadism. ${ }^{157}$ An interesting, not widely investigated association has been found between low total and free serum $\mathrm{T}$ levels and impaired pulmonary function evaluated by spirometry in the Tromsø study. ${ }^{116}$ Considering that oxygen therapy is known to increase $\mathrm{T}$ levels in men with respiratory failure, it seems more likely that poor, pulmonary function is responsible of lower $\mathrm{T}$ levels and not vice-versa, may be by altering the hypothalamic- 
pituitary function. ${ }^{158}$ The studies on COPD, however, are scanty and have been performed on small samples of patients, thus more data from more studies are still needed to better characterize hypogonadism in older men with COPD. ${ }^{22}$

Male hypogonadism is highly prevalent also in patients with chronic kidney disease as a consequence of testicular damage (primary hypogonadism). ${ }^{21,22,159}$ In patients who undergo hemodialysis for the first time hypogonadism do not normalize and tends to worsen, only renal transplantation being able to restore normal serum $\mathrm{T}^{21,22,159,160}$.

Several congenital systemic diseases might induce hypogonadism in the young, adult man and hypogonadism is intended to worsen with advancing age as in the case of $\beta$-thalassemia ${ }^{161}$ and hemocromatosis. ${ }^{162}$

Finally, treatments used for systemic chronic diseases might induce hypogonadism as in the case of rheumatoid arthritis. ${ }^{22,153}$ or treatment for cancer ${ }^{22}$

The issue concerning the relationship existing between morbidities and $\mathrm{LOH}$ is relevant since might to be bidirectional. ${ }^{40}$ On one hand, LOH sustains or exacerbates morbidities, while, on the other hand, $\mathrm{LOH}$ might be caused by comorbidities and might be reversible if comorbidities are treated. ${ }^{40}$ The same hormonal change occurs in patients with other acute illnesses different from infectious diseases. ${ }^{163-165}$ These changes seem to be part of a mechanism, which is adaptive to poor health status aiming to counteract the high catabolic state due to the acute, severe clinical condition. By decreasing the activity of the pituitary-gonadal axis it is possible to reduce some body functions (e.g., physical and sexual activity), thus allowing sparing energy and avoiding reproduction during a unhealthy condition. ${ }^{165}$ Since chronic diseases are associated to hypogonadism in the male, ${ }^{153,163}$ it has been postulated that in a part of men developing $\mathrm{T}$ deficiency with advancing age $\mathrm{LOH}$ maybe the consequence of multimorbidity that accumulates in the aging patient. ${ }^{40}$ With this in view, a considerable quote of $\mathrm{LOH}$ are not consistent with a clinical condition of hypogonadism, but represents an epiphenomenon of a poor health status, which is a common condition in the elderly. ${ }^{38,40}$ With this in view, hypogonadism could be considered as a functional, adaptive mechanism enrolled in presence of a condition of poor health status, ${ }^{40,50,165,166}$ as it happens in case of acute, severe illness.

Acute non-infectious diseases. Serum $\mathrm{T}$ might fall down in patients with acute, critical illnesses and normal serum $\mathrm{T}$ levels are restored by the resolution of the acute clinical condition. ${ }^{164,167,168}$ This condition occurs regardless the nature of the acute illness, ${ }^{163,164,169,170}$ it is associated to the severity of patients's clinical condition, ${ }^{163,168}$ and might be transitory and reversible. ${ }^{167,171}$ This mechanism based on a strict relationship between patient's poor health status and low serum $\mathrm{T}$ operates especially in aging men and share a mechanism involving the hypothalamus and the pituitary resulting in secondary hypogonadism. ${ }^{3,9,100,152}$

Aging, hypogonadism, and frailty. As mentioned above, patient's poor health status in terms of deteriorated clinical conditions might influence $\mathrm{T}$ secretion. In aging men, however, the more complicated, multidimensional concept named frailty should be also considered. ${ }^{172}$ Frailty depends not only by the clinical condition of the patients, but encompasses also all the physiological and pathological changes accumulating during aging that impair patients' physical performance (e.g., sarcopenia, osteoporosis, walking disabilities, impairment of visual acuity) as well as his pshychological status (loss of memory, depressed mood) and well-being. ${ }^{172-174}$ All these factors contribute to frailty and expose the aging man to experiment harmful events (e.g., falls, progressive reduction of physical activities). ${ }^{172-174}$

Frailty is inversely related to serum $\mathrm{T}$ in older men, as substantiated by several studies. ${ }^{15,17,154,175-177}$ Furthermore, sarcopenia is directly related to low serum $\mathrm{T}^{178}$ and takes part to the physiological process of aging itself. ${ }^{179-181}$ Even chronic illnesses are able to induce sarcopenia. ${ }^{180,182}$ Thus it is evident that sarcopenia should be considered as a central player in the relationships among LOH, frailty, and comorbidities. ${ }^{181}$

Aging, hypogonadism, and infectious diseases. Data available on the relationship among aging, hypogonadism, and infectious diseases are scanty. It is well known that sepsis induces a fall of serum $\mathrm{T}$ in men together with a decrease of serum $\mathrm{LH}$, consisting with a condition of hypogonadotropic hypogonadism. ${ }^{169,170}$ (Fig. 2). The same hormonal change occurs in patients with other acute illnesses different from infectious diseases ${ }^{163-165}$ These changes seem to be part of a mechanism, which is adaptive to poor health status aiming to counteract the high catabolic state due to the acute, severe clinical condition. By decreasing the activity of the pituitary-gonadal axis it is possible to reduce some body functions (e.g., physical and sexual activity), thus allowing sparing energy and avoiding reproduction during a unhealthy condition. ${ }^{165}$ Since chronic diseases are associated to hypogonadism in the male, ${ }^{153,163}$ it has been postulated that in a part of men developing $\mathrm{T}$ deficiency with advancing age $\mathrm{LOH}$ maybe the consequence of multimorbidity that accumulates in the aging patient. ${ }^{40}$ With this in view, a considerable quote of $\mathrm{LOH}$ are 
not consistent with a clinical condition of hypogonadism, but represents an epiphenomenon of a poor health status, which is a common condition in the elderly. ${ }^{38,40}$

Among infectious diseases that may interfere with circulating $\mathrm{T}$, rare testicular infections causing orchitis usually induce a temporary or permanent primary hypogonadism (hypergonadotropic hypogonadism) ${ }^{183}$ Conversely, chronic viral hepatitis are often related to an increase of serum total $\mathrm{T}$ rather to $\mathrm{T}$ deficiency; this condition is due to the rise of SHBG and does not modify free serum $\mathrm{T}^{184}$.

Hypogonadism and HIV infection. Among HIV infected-men a process of accelerated aging seems to take place, deriving from a multifactorial etiology (immunosenescence, inflammation, multimorbidity); therefore, HIV infection can be considered a model of premature aging. ${ }^{185}$ Accordingly, a premature decline of serum $\mathrm{T}$ has been described in this population. ${ }^{186}$ The prevalence of biochemical hypogonadism in HIVinfected men is around $25 \%$ in young-to-middle-aged men $^{50}$ and serum $\mathrm{T}$ decline in HIV-infected men aged 45-60 y seems to parallel what happens in older men after $60 .{ }^{50,186}$ In HIV-infected patients secondary hypogonadism is more common and is associated to fat redistribution and visceral adiposity. ${ }^{50,186}$ Furthermore, low levels of serum $\mathrm{T}$ are associated with to higher number of comorbidities and are inversely related to frailty. ${ }^{166}$ The latter finding does not help in establishing if these patients are truly hypogonadic or if their low $\mathrm{T}$ is related only to their poor health status.
The diagnosis of hypogonadism in these patients shares all the problems physicians have with older men and it is even more difficult due to the fact that symptoms and signs are much more less specific than in the general population. Sign and symptoms, especially those related to sexuality and body composition changes, overlap, in fact, with those of HIV infection. ${ }^{50}$

Finally, SHBG measurements is mandatory in men with HIV since SHBG alterations are very common in these patients and might lead to underestimation of hypogonadism. ${ }^{50}$

Serum $\mathrm{T}$ thresholds for $\mathrm{LOH}$ diagnosis. The cut-off of serum total $\mathrm{T}$ below which the diagnosis of overt biochemical hypogonadism could be formulated remains to be determined. Different studies, ${ }^{3,187,188}$ clinical guidelines ${ }^{12,25,33,148,154}$ (https://uroweb.org/guideline/male-hypo gonadism/), expert panels, ${ }^{49}$ and extensive literature revision. ${ }^{38-40,147}$ provided different cutoffs. However, all the cutoffs fall within the interval of serum total $\mathrm{T}$ comprised between $180 \mathrm{ng} / \mathrm{dL}$ and $300 \mathrm{ng} / \mathrm{dL}$ (Table 5).

Since $\mathrm{T}$ secretion follows a circadian rhythm, with peak values in the morning, $\mathrm{T}$ measurement should be performed in the morning, preferably in 2 different occasions $^{12,25,33,38,49,148,154}$ (https://uroweb.org/guideline/ male-hypogonadism/). When serum total $\mathrm{T}$ levels are borderline evaluation of free $\mathrm{T}$ can be useful, especially among older men who physiologically tend to have increased levels of $\mathrm{SHBG}^{33,154}$ In particular, SHBG measurement is indicated in obese patients and patients with chronic diseases (e.g., HIV-infection, viral hepatitis). ${ }^{25}$

Table 5. Serum testosterone (T) cutoffs suggested for the diagnosis of LOH.

\begin{tabular}{|c|c|c|c|}
\hline Cutoff Provider & Biochemical Hypogonadism & Gray Area (Mild Biochemical Hypogonadism) & Normal T \\
\hline & \multicolumn{3}{|c|}{ Serum total T ng/dL $(\mathrm{nmol} / \mathrm{L})$} \\
\hline Endocrine Society Guidelines & $<300(<10.4)$ & - & $>300(>10.4)$ \\
\hline AACE Guidelines & $202(<7)$ & - & $>202(>7.0)$ \\
\hline ISA, ISSAM, EAU, EAA, \& ASA Guidelines & $<231(<8)$ & $231<\mathrm{T}<346 \quad(8<T<12.0)$ & $>346(>12.0)$ \\
\hline EMAS Study & $<317(<11)$ & - & $>317(>11.0)$ \\
\hline HIMS Study ( $<5^{\text {th }}$ percentile) & $<185(<6.4)$ & - & $>185(>6.4)$ \\
\hline \multicolumn{4}{|l|}{ MMAS Study } \\
\hline $40-49$ yrs & $<251(<8.7)$ & - & $>251(>8.7)$ \\
\hline $50-59$ yrs & $<216(<7.5)$ & & $>216(>7.5)$ \\
\hline $60-69$ yrs & $<196(<6.8)$ & & $>196(>6.8)$ \\
\hline$>70$ yrs & $<156(<5.4)$ & & $>156(>5.4)$ \\
\hline \multirow[t]{2}{*}{ Australian Clinical Pathology Laboratories } & $<185(<6.4)$ & - & $>185(>6.4)$ \\
\hline & \multicolumn{3}{|c|}{ Serum free $\mathrm{T} p g / \mathrm{mL}(p m o l / L)$} \\
\hline ISA, ISSAM, EAU, EAA, \& ASA Guidelines & $<64.8(<225)$ & - & $>64.8(>225)$ \\
\hline EMAS Study & $<63,4(<220)$ & - & $>63.4(>220)$ \\
\hline
\end{tabular}

https://uroweb.org/guideline/male-hypogonadism/

Notes. T: testosterone; AACE: American Association of Clinical Endocrinologists; ISA: International Society of Andrology; ISSAM: International Society for the Study of the Aging Male; EAU: European Association of Urology, EAA: European Academy of Andrology; ASA: American Society of Andrology; EMAS: The European Male Aging Study; MMAS: The Massachusetts Male Aging Study. 
It is important to remark, however, that common laboratory assays used for free $\mathrm{T}$ measurement are not reliable and calculation of free $\mathrm{T}$ starting from total $\mathrm{T}$, albumin and SHBG with equations that have been validated should be preferred. ${ }^{3,13,14,25,148}$ Some guidelines ${ }^{12}$ or large longitudinal studies ${ }^{3}$ have provided thresholds also for calculated serum free T (http://www.issam.ch/ freetesto.htm) (Table 5).

Signs and symptoms of hypogonadism. The diagnosis of hypogonadism requires both biochemical measurements and clinical features ${ }^{12,25,33,38,49,148,154}$ (https://uroweb.org/ guideline/male-hypogonadism/). Since very often the symptoms suggestive of low $\mathrm{T}$ are attributed to age among older men, recognizing hypogonadism is not easy. ${ }^{15,148}$

The interview is essential in order to disclose symptoms of hypogonadism, which belong mainly to sexual and physical functions. ${ }^{12,25,33,38,49,148,154}$ (Fig. 3). The most specific symptoms related to the decrease of serum $\mathrm{T}$ are: reduced sexual desire (libido) and activity, decreased spontaneous erections in the morning, erectile dysfunction, reduced shaving frequency, decreased energy and vitality, and occasionally hot flushes ${ }^{3,12,25,38-40,49,147,148}$ (Fig. 3). Other symptoms are less specific (e.g., depressed mood and reduced muscle strength) ${ }^{12,25,33,38,49,148,154}$ (Fig. 3).

At physical examination, signs suggestive of hypogonadism should be investigated, such as reduced pubic and axillary hair, reduced testicular size and volume of ejaculation ${ }^{12,25,33,38,49,148,154}$ Figure 3 summarizes sign of hypogonadism according with to their specificity., 3,12,25,38-40,49,147,148

In conclusion, the best way for the diagnosis is to combine serum $\mathrm{T}$ (total or free) with the symptoms, ${ }^{3,38}$ regarding at $\mathrm{LH}$ as an adjunctive information useful to obtain a comprehensive picture of the pituitary gonadal axis and to find patients at higher risk to develop hypogonadism in the next future (compensated hypogonadism) ${ }^{90}$ (Figure 2).

Other examinations. If low serum total $\mathrm{T}$ is confirmed, measurement of serum $\mathrm{LH}$ and follicle-stimulating hormone (FSH) is recommended in order to identify primary or secondary hypogonadism (Figure 2). ${ }^{12,25,33,38,49,148,154}$ Both the conditions can be found in older men without specific endocrinological causes, nonetheless when LH and FSH levels are very low and suggest a central origin of hypogonadism, a global evaluation of pituitary function should be taken to exclude hypopituitarism. ${ }^{25,148}$

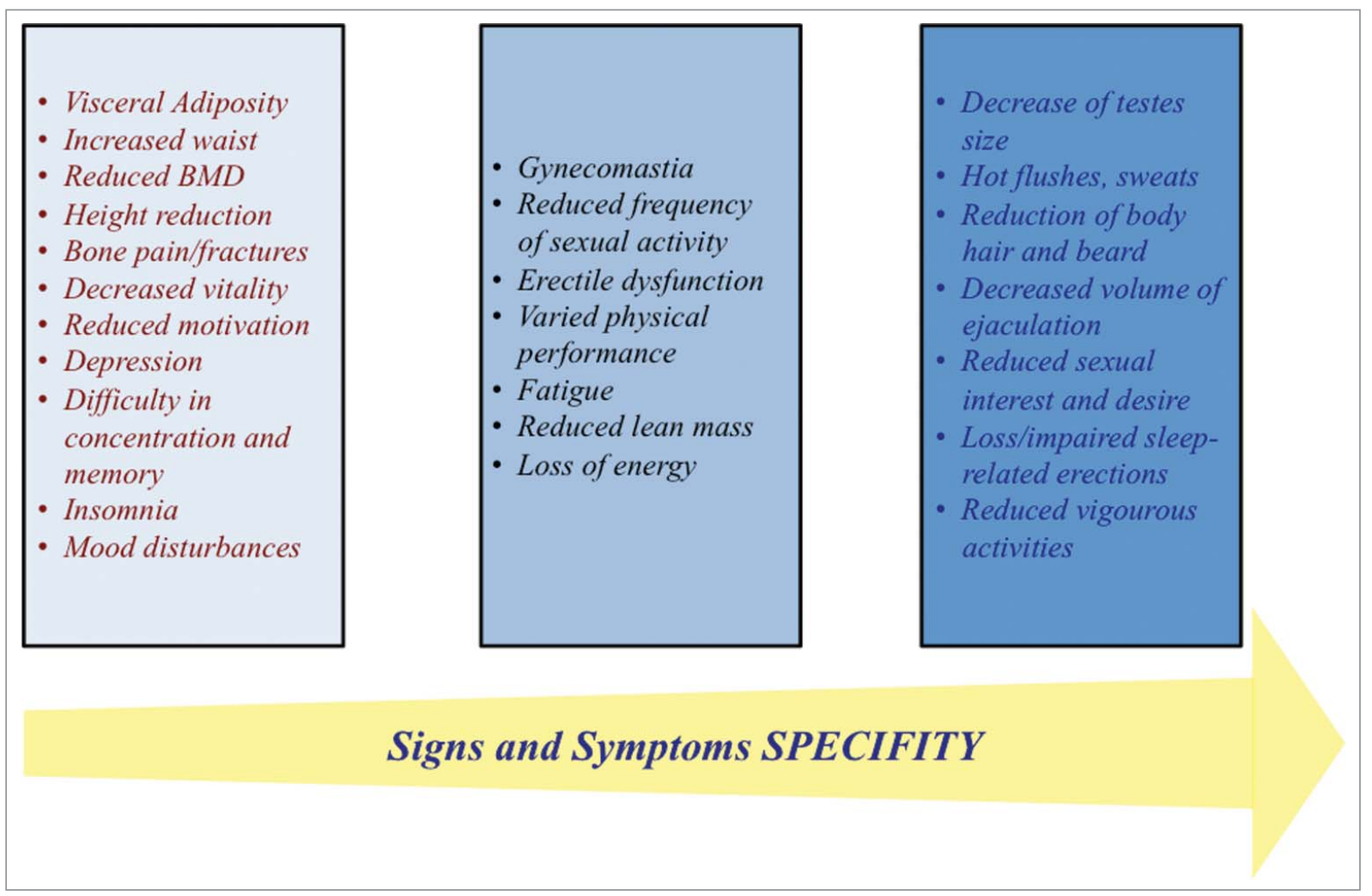

Figure 3. Signs and symptoms of late-onset hypogonadism according to their specificity. 
Finally, bone densitometry should be performed in case of low $\mathrm{T}$, because hypogonadism often is responsible for osteopenia, osteoporosis, and increased fracture risk in older men. ${ }^{48}$

\section{Testosterone replacement treatment: Certain knowledge and controversies}

Since many factors involved in low $\mathrm{T}$ onset are reversible, life-style modifications, such as smoke abolition and moderate alcohol consumption, physical activity and weight loss should be suggested not only to avoid hypogonadism, but also for general well-being in older age. ${ }^{147}$ Similarly, the resolution of acute illnesses. ${ }^{40,164,165}$ or the improvement of chronic diseases that might cause hypogonadism ${ }^{153}$ generally improve serum $\mathrm{T}$ as well as clinical condition in older men ${ }^{171}$

Patients who are candidate to receive $\mathrm{T}$ replacement are those with documented $\mathrm{LOH}$, concomitant symptoms and/or signs of low $\mathrm{T}$ (especially sexual symptoms) and no contraindication to $\mathrm{T}$ treatment. ${ }^{12,25,33,38,49,148,154}$ Treatment should be tailored according with to patient's health status and expectations after having considered the potential risk and after having informed the patients about possible risk and benefits. ${ }^{12,25,33,38,49,148,154}$ Evidence coming from randomized trials in men older than $60 \mathrm{y}$ is, in fact, still lacking and future large, prospective studies are required and worthwhile. ${ }^{189}$

At present, there is consensus against $\mathrm{T}$ treatment in men with a serum total $\mathrm{T}$ above $346 \mathrm{ng} / \mathrm{dL}(12 \mathrm{nmol} /$ L). ${ }^{12,38,49,154}$ or values of serum $\mathrm{T}$ very close to $346 \mathrm{ng} / \mathrm{dL}$ (https://uroweb.org/guideline/male-hypogonadism/).

$\mathrm{T}$ treatment is effective in improving sexual function, but this effect is not evident in men with normal serum $\mathrm{T}^{190}$. Other beneficial effects are related to the improvement of body composition and metabolic outcome ${ }^{40}$

It has been supposed that $\mathrm{T}$ treatment might increase $\mathrm{CV}$ risk (http://www.fda.gov/Drugs/DrugSafety/ucm436259. $\mathrm{htm}$ ) on the basis of CV events reported in some of the T trials. ${ }^{189,191-194}$ However, at present 4 different metaanalyses have not found this association to be consistent, ${ }^{194-197}$ while only one confirmed an increased CV risk due to T treatment. ${ }^{198}$

Contraindications are documented prostate and breast cancer, and strong caution should be used when hematocrit is increased $(>50 \%) .^{12,25,33,38,49,148,154}$ Other aspects that should be considered are congestive heart failure, sleep apnea, benign prostatic hyperplasia and a prostate specific antigen (PSA) $>4 \mathrm{ng} / \mathrm{mL}^{12,25,33,38,49,148,154}$ Furthermore, patients with a recent (within 6 months) history of $\mathrm{CV}$ events should not be considered as candidate to receive $\mathrm{T}$ replacement treatment. ${ }^{38,40,49,189}$
The patient should be informed about potential benefits that involve mainly sexual desire and function, vigor, body composition changes and prevention of bone loss. At the same time, patient should be aware that $\mathrm{T}$ treatment in older men might be harmful and that evidence in favor of its safety is not of good quality.

\section{Unresolved issues}

Sexual symptoms are the most useful to prompt the diagnosis of $\mathrm{LOH}$, but they are also difficult to unmask in the consistent percentage of patients (especially older men) who are reluctant to talk about them with physicians. ${ }^{199}$ In addition, even physicians are less prone to interview aging men about their sexuality. ${ }^{200}$

We know that among men with a diagnosis of $\mathrm{LOH}$ there are false positive and that this diagnosis is probably overlooked in other men (false negative). However, it is very difficult to have precise data concerning the accuracy of $\mathrm{LOH}$ diagnosis due to the lack of certain diagnostic criteria.

Concerning the diagnosis of $\mathrm{LOH}$, there is still a gap of knowledge about the significance of great serum $\mathrm{T}$ decrease from the baseline overtime (e.g., 50\%) leading to a serum value still in the range of eugonadism, but much lower than in the past. It is possible that patients with this kind of serum $\mathrm{T}$ decline trajectory become truly hypogonadal and already display sign and symptoms of hypogonadism. ${ }^{38}$ Furthermore, data on the natural history of $\mathrm{LOH}$ are scanty. ${ }^{171}$

From literature we know that $\mathrm{LOH}$ might be reversible in about half of the patients, ${ }^{171}$ but at present we are not able to predict, among patients with $\mathrm{LOH}$, who will return to normal androgenization, except for those patients who are obese or overweight and loose weight. ${ }^{147}$

In the field of geriatrics is getting growing importance the concept of frailty, which is defined as a condition of vulnerability to stressing events. The condition of frailty derives from accumulation of deficits in multiple physiological systems and can be quantified by a frailty index. At present, the impact of $\mathrm{T}$ decline on frailty remains to be determined. Accordingly, it is not clear if T treatment is able to improve or worsen frailty in older men. Similarly, the potential for $\mathrm{T}$ treatment to be harmful in sick older men or in men with HIV infection and a poor health status remains an unsolved issue. ${ }^{189}$

At present, no association between serum $\mathrm{T}$ and life expectancy was found by comparing long-lived with shortlived subjects. ${ }^{201}$ However, differences in lifespan between men and women suggest a putative role of sex hormones on longevity. ${ }^{202}$ What we know is that lifespan was not different between singers castrated before puberty and non-castrated singers, suggesting that $\mathrm{T}$ does not influence longevity. ${ }^{203} \mathrm{~T}$, 
probably might protect centrally from the effects of stress by mitigating the central cascade of events induced by the exposure to stress, while women are more exposed the negative effect of stress. ${ }^{204}$ How much gender differences in the exposure to sex steroids at any age are involved in determining longevity and the response to stress remains to be established in detail. ${ }^{202,204}$

\section{Conclusions}

The decline of sex steroids with advancing age depends on gender and interindividual differences. In men physiological changes should be differentiated from pathological low serum $\mathrm{T}$ and the coupling low serum $\mathrm{T}$ with hypogonadism-related signs and symptoms is a good strategy to diagnose $\mathrm{LOH}$ and to identify patients who might beneficiate from $\mathrm{T}$ replacement. However, the specificity of symptoms of hypogonadism is low and measurements of serum $\mathrm{T}$ insidious, thus all these factors increase the risk of misdiagnosis. The presence/absence of concomitant acute or chronic illnesses could lead the physician avoiding misdiagnosis and overtreatment. Patients' health status, in fact, should be taken into account prior to start $\mathrm{T}$ treatment to prevent adverse events that are more common in men with poor clinical conditions. Replacement treatment might be effective in improving sexual function, body composition, metabolic outcome, and vitality. In older men $\mathrm{T}$ treatment is not based on good evidence and the patient should be informed about the lack of proven beneficial effects as well as on the possible side effects and adverse events.

\section{Abbreviations}

\begin{tabular}{|c|c|}
\hline AACE & $\begin{array}{l}\text { American Association of Clinical } \\
\text { Endocrinologists }\end{array}$ \\
\hline ASA & American Society of Andrology \\
\hline BLSA & $\begin{array}{l}\text { The Baltimore Longitudinal Study of } \\
\text { Aging }\end{array}$ \\
\hline BMD & bone mineral density \\
\hline BMI & body mass index \\
\hline CHAMP & $\begin{array}{l}\text { The Concorde Health and Aging in Men } \\
\text { Project }\end{array}$ \\
\hline COPD & chronic obstructive pulmonary disease \\
\hline $\mathrm{CV}$ & cardiovascular \\
\hline $\mathrm{E}_{2}$ & estradiol \\
\hline EAA & European Academy of Andrology \\
\hline EAU & European Association of Urology \\
\hline $\mathrm{ED}$ & erectile dysfunction \\
\hline EMAS & European Male Aging Study \\
\hline $\mathrm{F}$ & females \\
\hline FSH & follicle-stimulating hormone \\
\hline
\end{tabular}

\begin{tabular}{|c|c|}
\hline $\mathrm{fT}$ & free testosterone \\
\hline $\mathrm{GH}$ & growth hormone \\
\hline GnRH & gonadotropin-releasing hormone \\
\hline HIMS & The Health in Men Study \\
\hline HIV & Human Immunodeficiency Virus \\
\hline IAs & Immunoassays \\
\hline IGF-1 & insulin-like growth facotor-1 \\
\hline ISA & International Society of Andrology \\
\hline ISSAM & $\begin{array}{l}\text { International Society for the Study of the } \\
\text { Aging Male }\end{array}$ \\
\hline LC-MS/MS & $\begin{array}{l}\text { liquid chromatography-tandem mass } \\
\text { spectrometry }\end{array}$ \\
\hline LH & luteinizing hormone \\
\hline $\mathrm{LOH}$ & late-onset hypogonadism \\
\hline M & males \\
\hline MC-PLOC-B & $\begin{array}{l}\text { MultiCenter, Prospective, Longitudinal, } \\
\text { Observational, Community-Based Study }\end{array}$ \\
\hline MMAS & The Massachusetts Male Aging Study \\
\hline MrOS & $\begin{array}{l}\text { The Osteoporotic Fractures in men } \\
\text { Study }\end{array}$ \\
\hline MS & mass spectrometry \\
\hline n.a. & not available \\
\hline P-BRT & Population-Based, Randomized, Trial \\
\hline PLOC-B & $\begin{array}{l}\text { Prospective, Longitudinal, Observational, } \\
\text { Community-Based Study }\end{array}$ \\
\hline PSA & prostate specific antigen \\
\hline RBS & The Rancho Bernardo Study \\
\hline SHBG & sex-hormone binding globuline \\
\hline $\mathrm{T}$ & testosterone \\
\hline TSH & thyrotropin hormone \\
\hline TT & total testosterone \\
\hline US & ultrasonography. \\
\hline
\end{tabular}

\section{Disclosure of potential conflicts of interest}

No potential conflicts of interest were disclosed.

\section{Acknowledgments}

The authors thank Prof. Paola Ugolini, Department of Romance Languages, SUNY Buffalo, NY, USA for having proofread the manuscript.

\section{ORCID}

Vincenzo Rochira iD http://orcid.org/0000-0001-8169-0696

\section{References}

[1] Veldhuis JD. Changes in pituitary function with ageing and implications for patient care. Nat Rev Endocrinol 2013; 9:205-15; PMID:23438832; https://doi.org/ 10.1038 /nrendo.2013.38

[2] Al-Safi Z, Santoro N. The Postmenopausal Woman. In: De Groot LJ, Beck-Peccoz P, Chrousos G, Dungan K, 
Grossman A, Hershman JM, Koch C, McLachlan R, New M, Rebar R, et al., eds. Endotext. South Dartmouth MA: MDText.com, Inc., 2000.

[3] Wu FC, Tajar A, Beynon JM, Pye SR, Silman AJ, Finn JD, O’Neill TW, Bartfai G, Casanueva FF, Forti $\mathrm{G}$, et al. Identification of late-onset hypogonadism in middle-aged and elderly men. N Engl J Med 2010; 363:123-35; PMID:20554979; https://doi.org/10.1056/ NEJMoa0911101

[4] Harman SM, Metter EJ, Tobin JD, Pearson J, Blackman MR. Longitudinal effects of aging on serum total and free testosterone levels in healthy men. Baltimore Longitudinal Study of Aging. J Clin Endocrinol Metabolism 2001; 86:724-31; https://doi. org/10.1210/jcem.86.2.7219

[5] Kaufman JM, Vermeulen A. The decline of androgen levels in elderly men and its clinical and therapeutic implications. Endocr Rev 2005; 26:833-76; PMID:15901667; https://doi.org/10.1210/er.2004-0013

[6] Zmuda JM, Cauley JA, Kriska A, Glynn NW, Gutai JP, Kuller LH. Longitudinal relation between endogenous testosterone and cardiovascular disease risk factors in middle-aged men. A 13-year follow-up of former Multiple Risk Factor Intervention Trial participants. Am J Epidemiol 1997; 146:609-17; PMID:9345114; https:// doi.org/10.1093/oxfordjournals.aje.a009326

[7] Vermeulen A, Kaufman JM, Giagulli VA. Influence of some biological indexes on sex hormone-binding globulin and androgen levels in aging or obese males. J Clin Endocrinol Metabol 1996; 81:1821-6.

[8] Araujo AB, O’Donnell AB, Brambilla DJ, Simpson WB, Longcope C, Matsumoto AM, McKinlay JB. Prevalence and incidence of androgen deficiency in middle-aged and older men: estimates from the Massachusetts Male Aging Study. J Clin Endocrinol Metabol 2004; 89:59206; https://doi.org/10.1210/jc.2003-031719

[9] Mulligan T, Frick MF, Zuraw QC, Stemhagen A, McWhirter C. Prevalence of hypogonadism in males aged at least 45 years: the HIM study. Int J Clin Pract 2006; 60:762-9; PMID:16846397; https://doi.org/ 10.1111/j.1742-1241.2006.00992.x

[10] Schneider HJ, Sievers C, Klotsche J, Bohler S, Pittrow D, Lehnert H, Wittchen HU, Stalla GK. Prevalence of low male testosterone levels in primary care in Germany: cross-sectional results from the DETECT study. Clin Endocrinol 2009; 70:446-54; https://doi.org/10.1111/ j.1365-2265.2008.03370.x

[11] Handelsman DJ. Androgen Physiology, Pharmacology and Abuse. In: De Groot LJ, Beck-Peccoz P, Chrousos G, Dungan K, Grossman A, Hershman JM, Koch C, McLachlan R, New M, Rebar R, et al., eds. Endotext. South Dartmouth MA: MDText.com, Inc., 2000.

[12] Wang C, Nieschlag E, Swerdloff R, Behre HM, Hellstrom WJ, Gooren LJ, Kaufman JM, Legros JJ, Lunenfeld B, Morales A, et al. Investigation, treatment, and monitoring of late-onset hypogonadism in males: ISA, ISSAM, EAU, EAA, and ASA recommendations. J Androl 2009; 30:1-9; PMID:18772485; https://doi.org/ 10.2164/jandrol.108.006486

[13] Vermeulen A, Verdonck L, Kaufman JM. A critical evaluation of simple methods for the estimation of free testosterone in serum. J Clin Endocrinol Metabol 1999; 84:3666-72; https://doi.org/10.1210/jcem.84.10.6079

[14] Ly LP, Sartorius G, Hull L, Leung A, Swerdloff RS, Wang C, Handelsman DJ. Accuracy of calculated free testosterone formulae in men. Clin Endocrinol 2010; 73:382-8; https://doi.org/10.1111/j.13652265.2010.03804.x

[15] Travison TG, Araujo AB, Kupelian V, O’Donnell AB, McKinlay JB. The relative contributions of aging, health, and lifestyle factors to serum testosterone decline in men. J Clin Endocrinol Metabol 2007; 92:549-55; https://doi.org/10.1210/jc.2006-1859

[16] Lapauw B, Goemaere S, Zmierczak H, Van Pottelbergh I, Mahmoud A, Taes Y, De Bacquer D, Vansteelandt S, Kaufman JM. The decline of serum testosterone levels in community-dwelling men over 70 years of age: descriptive data and predictors of longitudinal changes. Eur J Endocrinol/Eur Federat Endocrine Soc 2008; 159:459-68; https://doi.org/10.1530/EJE-07-0873

[17] Tajar A, O’Connell MD, Mitnitski AB, O’Neill TW, Searle SD, Huhtaniemi IT, Finn JD, Bartfai G, Boonen $\mathrm{S}$, Casanueva FF, et al. Frailty in relation to variations in hormone levels of the hypothalamic-pituitary-testicular axis in older men: results from the European male aging study. J Am Geriatrics Soc 2011; 59:814-21; https://doi. org/10.1111/j.1532-5415.2011.03398.x

[18] Antonio L, Wu FC, O’Neill TW, Pye SR, Carter EL, Finn JD, Rutter MK, Laurent MR, Huhtaniemi IT, Han TS, et al. Associations between sex steroids and the development of metabolic syndrome: a longitudinal study in European men. J Clin Endocrinol Metabol 2015; 100:1396-404; https://doi.org/10.1210/jc.20144184

[19] Brand JS, Rovers MM, Yeap BB, Schneider HJ, Tuomainen TP, Haring R, Corona G, Onat A, Maggio $\mathrm{M}$, Bouchard C, et al. Testosterone, sex hormone-binding globulin and the metabolic syndrome in men: an individual participant data meta-analysis of observational studies. PloS One 2014; 9:e100409; PMID:25019163; https://doi.org/10.1371/journal.pone.0100409

[20] Corona G, Rastrelli G, Monami M, Saad F, Luconi M, Lucchese M, Facchiano E, Sforza A, Forti G, Mannucci E, et al. Body weight loss reverts obesity-associated hypogonadotropic hypogonadism: a systematic review and meta-analysis. Eur J Endocrinol/Euro Federat Endocrine Soc 2013; 168:829-43; https://doi.org/ 10.1530/EJE-12-0955

[21] Palmer BF, Clegg DJ. Gonadal dysfunction in chronic kidney disease. Rev Endoc Metab Dis 2016.

[22] Karagiannis A, Harsoulis F. Gonadal dysfunction in systemic diseases. Eur J Endocrinol/Euro Federat Endocrine Soc 2005; 152:501-13; https://doi.org/10.1530/ eje.1.01886

[23] Simoni MFF, Roli L, Pagotto U. Methodology for measuring testosterone, dihydrotestosterone and sex hormone-binding globulin in a clinical setting. In: Behre ENHM, ed. Testosterone Action, Deficiency, Substitution. Cambridge, UK: Cambridge University Press, 2012:60-86.

[24] Winters SJ. Laboratory Assessment of Testicular Function. In: De Groot LJ, Beck-Peccoz P, Chrousos G, 
Dungan K, Grossman A, Hershman JM, Koch C, McLachlan R, New M, Rebar R, et al., eds. Endotext. South Dartmouth MA: MDText.com, Inc., 2000.

[25] Bhasin S, Cunningham GR, Hayes FJ, Matsumoto AM, Snyder PJ, Swerdloff RS, Montori VM. Testosterone therapy in men with androgen deficiency syndromes: an Endocrine Society clinical practice guideline. J Clin Endocrinol Metabol 2010; 95:2536-59; https://doi.org/ 10.1210/jc.2009-2354

[26] Wang Y, Gay GD, Botelho JC, Caudill SP, Vesper HW. Total testosterone quantitative measurement in serum by LC-MS/MS. Clinica Chimica Acta; Int J Clin Chem 2014; 436:263-7; PMID:24960363; https://doi.org/ 10.1016/j.cca.2014.06.009

[27] Wang C, Catlin DH, Demers LM, Starcevic B, Swerdloff RS. Measurement of total serum testosterone in adult men: comparison of current laboratory methods versus liquid chromatography-tandem mass spectrometry. J Clin Endocrinol Metabol 2004; 89:534-43; https://doi. org/10.1210/jc.2003-031287

[28] Fanelli F, Belluomo I, Di Lallo VD, Cuomo G, De Iasio R, Baccini M, Casadio E, Casetta B, Vicennati V, Gambineri A, et al. Serum steroid profiling by isotopic dilution-liquid chromatography-mass spectrometry: comparison with current immunoassays and reference intervals in healthy adults. Steroids 2011; 76:244-53; PMID:21112348; https://doi.org/ 10.1016/j.steroids.2010.11.005

[29] Rosner W, Auchus RJ, Azziz R, Sluss PM, Raff H. Position statement: utility, limitations, and pitfalls in measuring testosterone: an Endocrine Society position statement. J Clin Endocrinol Metabol 2007; 92:405-13; https://doi.org/10.1210/jc.2006-1864

[30] Rosner W, Vesper H. Toward excellence in testosterone testing: a consensus statement. J Clin Endocrinol Metabol 2010; 95:4542-8; https://doi.org/10.1210/ jc.2010-1314

[31] Ketha H, Kaur S, Grebe SK, Singh RJ. Clinical applications of LC-MS sex steroid assays: evolution of methodologies in the 21st century. Curr Opin Endocrinol, Diab Obes 2014; 21:217-26; PMID:24739314; https://doi.org/ 10.1097/MED.0000000000000068

[32] Huhtaniemi IT, Tajar A, Lee DM, O’Neill TW, Finn JD, Bartfai G, Boonen S, Casanueva FF, Giwercman A, Han TS, et al. Comparison of serum testosterone and estradiol measurements in 3174 European men using platform immunoassay and mass spectrometry; relevance for the diagnostics in aging men. Euro J Endocrinol/ Euro Federat Endocrine Soc 2012; 166:983-91; https:// doi.org/10.1530/EJE-11-1051

[33] Morales A, Bebb RA, Manjoo P, Assimakopoulos P, Axler J, Collier C, Elliott S, Goldenberg L, Gottesman I, Grober ED, et al. Diagnosis and management of testosterone deficiency syndrome in men: clinical practice guideline. CMAJ: Canadian Med Assoc J = J de l'Assoc Med Canadienne 2015; 187:1369-77; PMID:26504097; https://doi.org/10.1503/cmaj.150033

[34] Bremner WJ, Vitiello MV, Prinz PN. Loss of circadian rhythmicity in blood testosterone levels with aging in normal men. J Clin Endocrinol Metabol 1983; 56:127881; https://doi.org/10.1210/jcem-56-6-1278
[35] Brambilla DJ, O'Donnell AB, Matsumoto AM, McKinlay JB. Intraindividual variation in levels of serum testosterone and other reproductive and adrenal hormones in men. Clin Endocrinol 2007; 67:853-62; PMID:18052942; https://doi.org/10.1111/j.1365-2265.2007.02976.x

[36] Gonzalez-Sales M, Barriere O, Tremblay PO, Nekka F, Desrochers J, Tanguay M. Modeling testosterone circadian rhythm in hypogonadal males: effect of age and circannual variations. AAPS J 2016; 18:217-27; PMID:26553482; https://doi.org/10.1208/s12248-0159841-6

[37] Feldman HA, Longcope C, Derby CA, Johannes CB, Araujo AB, Coviello AD, Bremner WJ, McKinlay JB. Age trends in the level of serum testosterone and other hormones in middle-aged men: longitudinal results from the Massachusetts male aging study. J Clin Endocrinol Metabol 2002; 87:589-98; https://doi.org/10.1210/ jcem.87.2.8201

[38] Huhtaniemi I. Late-onset hypogonadism: current concepts and controversies of pathogenesis, diagnosis and treatment. Asian J Androl 2014; 16:192-202; PMID:24407185; $\quad$ https://doi.org/10.4103/1008-68 2X.122336

[39] Corona G, Rastrelli G, Vignozzi L, Mannucci E, Maggi M. How to recognize late-onset hypogonadism in men with sexual dysfunction. Asian J Androl 2012; 14:251-9; PMID:22286862; https://doi.org/10.1038/aja.2011.138

[40] Corona G, Maseroli E, Rastrelli G, Francomano D, Aversa A, Hackett G, Ferri S, Sforza A, Maggi M. Is late-onset hypogonadotropic hypogonadism a specific age-dependent disease, or merely an epiphenomenon caused by accumulating disease-burden? Focusing on metabolic diseases. Minerva Endocrinol 2016; PMID:26883937

[41] Rodriguez A, Muller DC, Metter EJ, Maggio M, Harman SM, Blackman MR, Andres R. Aging, androgens, and the metabolic syndrome in a longitudinal study of aging. J Clin Endocrinol Metabol 2007; 92:3568-72; https://doi. org/10.1210/jc.2006-2764

[42] Rochira V, Kara E, Carani C. The endocrine role of estrogens on human male skeleton. Int J Endocrinol 2015; 2015:165215; PMID:25873947; https://doi.org/ $10.1155 / 2015 / 165215$

[43] Mellstrom D, Vandenput L, Mallmin H, Holmberg AH, Lorentzon M, Oden A, Johansson H, Orwoll ES, Labrie F, Karlsson MK, et al. Older men with low serum estradiol and high serum SHBG have an increased risk of fractures. J Bone Mineral Res: Off J Am Soc Bone Min Res 2008; 23:1552-60; PMID:18518773; https://doi.org/ 10.1359/jbmr.080518

[44] Rochira V, Zirilli L, Genazzani AD, Balestrieri A, Aranda C, Fabre B, Antunez P, Diazzi C, Carani C, Maffei L. Hypothalamic-pituitary-gonadal axis in two men with aromatase deficiency: evidence that circulating estrogens are required at the hypothalamic level for the integrity of gonadotropin negative feedback. Euro J Endocrinol/ Eur Federat Endocrine Soc 2006; 155:513-22; https://doi.org/10.1530/ eje.1.02254

[45] Finkelstein JS, Lee H, Burnett-Bowie SA, Pallais JC, Yu EW, Borges LF, Jones BF, Barry CV, Wulczyn KE, 
Thomas BJ, et al. Gonadal steroids and body composition, strength, and sexual function in men. $\mathrm{N}$ Engl J Med 2013; 369:1011-22; PMID:24024838; https://doi. org/10.1056/NEJMoa1206168

[46] Carani C, Rochira V, Faustini-Fustini M, Balestrieri A, Granata AR. Role of oestrogen in male sexual behaviour: insights from the natural model of aromatase deficiency. Clin Endocrinol 1999; 51:517-24; PMID:10583321; https://doi.org/10.1046/j.1365-2265.1999.00849.x

[47] Cunningham GR, Stephens-Shields AJ, Rosen RC, Wang C, Ellenberg SS, Matsumoto AM, Bhasin S, Molitch ME, Farrar JT, Cella D, et al. Association of sex hormones with sexual function, vitality, and physical function of symptomatic older men with low testosterone levels at baseline in the testosterone trials. J Clin Endocrinol Metabol 2015; 100:1146-55; https://doi.org/ 10.1210/jc.2014-3818

[48] Rochira V, Balestrieri A, Madeo B, Zirilli L, Granata AR, Carani C. Osteoporosis and male age-related hypogonadism: role of sex steroids on bone (patho)physiology. Euro J Endocrinol / Euro Federat Endocrine Soc 2006; 154:175-85; https://doi.org/10.1530/eje.1.02088

[49] Buvat J, Maggi M, Guay A, Torres LO. Testosterone deficiency in men: systematic review and standard operating procedures for diagnosis and treatment. J Sex Med 2013; 10:245-84; PMID:22971200; https://doi.org/ 10.1111/j.1743-6109.2012.02783.x

[50] Rochira V, Guaraldi G. Hypogonadism in the HIVinfected man. Endocrinol Metab Clin North Am 2014; 43:709-30; PMID:25169563; https://doi.org/10.1016/j. ecl.2014.06.005

[51] Rosner W, Hankinson SE, Sluss PM, Vesper HW, Wierman ME. Challenges to the measurement of estradiol: an endocrine society position statement. J Clin Endocrinol Metabol 2013; 98:1376-87; https://doi. org/10.1210/jc.2012-3780

[52] Morley JE, Kaiser FE, Perry HM, 3rd, Patrick P, Morley PM, Stauber PM, Vellas B, Baumgartner RN, Garry PJ. Longitudinal changes in testosterone, luteinizing hormone, and follicle-stimulating hormone in healthy older men. Metabol: Clin Exp 1997; 46:410-3; PMID:9109845; https://doi.org/10.1016/S0026-0495(97)90057-3

[53] Gray A, Feldman HA, McKinlay JB, Longcope C. Age, disease, and changing sex hormone levels in middleaged men: results of the Massachusetts Male Aging Study. J. Clin. Endocrinol. Metabol. 1991; 73:1016-25; https://doi.org/10.1210/jcem-73-5-1016

[54] Gray A, Berlin JA, McKinlay JB, Longcope C. An examination of research design effects on the association of testosterone and male aging: results of a meta-analysis. J Clin Epidemiol 1991; 44:671-84; PMID:1829756; https://doi.org/10.1016/0895-4356(91)90028-8

[55] Deslypere JP, Vermeulen A. Leydig cell function in normal men: effect of age, life-style, residence, diet, and activity. J Clin Endocrinol Metabol 1984; 59:955-62; https://doi.org/10.1210/jcem-59-5-955

[56] Baker HW, Burger HG, de Kretser DM, Hudson B, O'Connor S, Wang C, Mirovics A, Court J, Dunlop $\mathrm{M}$, Rennie GC. Changes in the pituitary-testicular system with age. Clin Endocrinol 1976; 5:349-72; PMID:971543; https://doi.org/10.1111/j.1365-2265. 1976.tb01964.x
[57] Seftel AD. Male hypogonadism. Part I: epidemiology of hypogonadism. Int J Impot Res 2006; 18:115-20.

[58] Stone JL, Norris AH. Activities and attitudes of participants in the Baltimore longitudinal study. J Gerontol 1966; 21:575-80; PMID:5918312; https://doi.org/ 10.1093/geronj/21.4.575

[59] Greendale GA, Edelstein S, Barrett-Connor E. Endogenous sex steroids and bone mineral density in older women and men: the Rancho Bernardo Study. J Bone Min Res: Off J Am Soc Bone Min Res 1997; 12:1833-43; PMID:9383688; https://doi.org/ 10.1359/jbmr.1997.12.11.1833

[60] Bjornerem A, Straume B, Midtby M, Fonnebo V, Sundsfjord J, Svartberg J, Acharya G, Oian P, Berntsen GK. Endogenous sex hormones in relation to age, sex, lifestyle factors, and chronic diseases in a general population: the Tromso Study. J Clin Endocrinol Metabol 2004; 89:6039-47; https://doi.org/ 10.1210/jc.2004-0735

[61] Mohr BA, Guay AT, O’Donnell AB, McKinlay JB. Normal, bound and nonbound testosterone levels in normally ageing men: results from the Massachusetts Male Ageing Study. Clin Endocrinol 2005; 62:64-73; PMID:15638872; $\quad$ https://doi.org/10.1111/j.13652265.2004.02174.x

[62] Orwoll E, Blank JB, Barrett-Connor E, Cauley J, Cummings S, Ensrud K, Lewis C, Cawthon PM, Marcus R, Marshall LM, et al. Design and baseline characteristics of the osteoporotic fractures in men (MrOS) study-a large observational study of the determinants of fracture in older men. Contemp Clin Trials 2005; 26:569-85; PMID:16084776; https:// doi.org/10.1016/j.cct.2005.05.006

[63] Lee DM, O’Neill TW, Pye SR, Silman AJ, Finn JD, Pendleton N, Tajar A, Bartfai G, Casanueva F, Forti G, et al. The European Male Ageing Study (EMAS): design, methods and recruitment. Int J Androl 2009; 32:11-24; PMID:18328041; https://doi.org/10.1111/ j.1365-2605.2008.00879.x

[64] Lee DM, Pye SR, Tajar A, O’Neill TW, Finn JD, Boonen S, Bartfai G, Casanueva FF, Forti G, Giwercman A, et al. Cohort profile: the European male ageing study. Int J Epidemiol 2013; 42:391-401; PMID:22314965; https:// doi.org/10.1093/ije/dyr234

[65] Barrett-Connor E. The Rancho Bernardo Study: 40 years studying why women have less heart disease than men and how diabetes modifies women's usual cardiac protection. Global heart 2013; 8; PMID:24187655; https:// doi.org/10.1016/j.gheart.2012.12.002

[66] Maggio M, Lauretani F, Ceda GP, Bandinelli S, Ling SM, Metter EJ, Artoni A, Carassale L, Cazzato A, Ceresini G, et al. Relationship between low levels of anabolic hormones and 6-year mortality in older men: the aging in the Chianti Area (InCHIANTI) study. Arch Int Med 2007; 167:2249-54; PMID:17998499; https:/doi.org/ 10.1001/archinte.167.20.2249

[67] Maggio M, Lauretani F, Ceda GP, Bandinelli S, Basaria S, Paolisso G, Giumelli C, Luci M, Najjar SS, Metter EJ, et al. Estradiol and metabolic syndrome in older italian men: the InCHIANTI Study. J Androl 2010; 31:155-62; PMID:19059904; https://doi.org/10.2164/ jandrol.108.006098 
[68] Maggio M, Lauretani F, Ceda GP, Bandinelli S, Basaria S, Ble A, Egan J, Paolisso G, Najjar S, Jeffrey Metter E, et al. Association between hormones and metabolic syndrome in older Italian men. Journal of the American Geriatrics Society 2006; 54:1832-8; PMID:17198487; https://doi.org/10.1111/j.1532-5415.2006.00963.x

[69] Maggio M, Ceda GP, Lauretani F, Bandinelli S, Metter EJ, Guralnik JM, Basaria S, Cattabiani C, Luci M, Dall'Aglio E, et al. Gonadal status and physical performance in older men. Aging Male: Off J Int Soc Study Aging Male 2011; 14:42-7; PMID:20937007; https://doi.org/10.3109/13685538.2010.518179

[70] Maggio M, Cattabiani C, Lauretani F, Artoni A, Bandinelli S, Schiavi G, Vignali A, Volpi R, Ceresini G, Lippi $\mathrm{G}$, et al. The relationship between sex hormones, sex hormone binding globulin and peripheral artery disease in older persons. Atherosclerosis 2012; 225:46974; PMID:23102785; https://doi.org/10.1016/j. atherosclerosis.2012.09.014

[71] Bjornerem A, Emaus N, Berntsen GK, Joakimsen RM, Fonnebo V, Wilsgaard T, Oian P, Seeman E, Straume B. Circulating sex steroids, sex hormone-binding globulin, and longitudinal changes in forearm bone mineral density in postmenopausal women and men: the Tromso study. Calcified Tissue Int 2007; 81:65-72; PMID: 17612780; https://doi.org/10.1007/s00223-007-9035-Z

[72] Bjornerem A, Ahmed LA, Joakimsen RM, Berntsen GK, Fonnebo V, Jorgensen L, Oian P, Seeman E, Straume B. A prospective study of sex steroids, sex hormone-binding globulin, and non-vertebral fractures in women and men: the Tromso Study. Euro Endocrinol / Euro Federat Endocrine Soc 2007; 157:119-25; https://doi.org/ 10.1530/EJE-07-0032

[73] Cumming RG, Handelsman D, Seibel MJ, Creasey H, Sambrook P, Waite L, Naganathan V, Le Couteur D, Litchfield M. Cohort profile: the concord health and ageing in Men project (CHAMP). Int J Epidemiol 2009; 38:374-8; PMID:18480109; https://doi.org/10.1093/ije/ dyn071

[74] Hsu B, Cumming RG, Blyth FM, Naganathan V, Le Couteur DG, Seibel MJ, Waite LM, Handelsman DJ. The longitudinal relationship of sexual function and androgen status in older men: the Concord Health and Ageing in Men Project. J Clin Endocrinol Metabol 2015; 100:1350-8; https://doi.org/10.1210/jc.2014-4104

[75] Hsu B, Cumming RG, Blyth FM, Naganathan V, Le Couteur DG, Seibel MJ, Waite LM, Handelsman DJ. Longitudinal and cross-sectional relationships of circulating reproductive hormone levels to self-rated health and health-related quality of life in community-dwelling older men. J Clin Endocrinol Metabol 2014; 99:1638-47; https://doi.org/10.1210/jc.2013-3984

[76] Hsu B, Cumming RG, Naganathan V, Blyth FM, Le Couteur DG, Seibel MJ, Waite LM, Handelsman DJ. Associations between circulating reproductive hormones and SHBG and prevalent and incident metabolic syndrome in community-dwelling older men: the Concord Health and Ageing in Men Project. J Clin Endocrinol Metabol 2014; 99:E2686-91; https://doi.org/10.1210/ jc.2014-2464

[77] Hsu B, Cumming RG, Hirani V, Blyth FM, Naganathan V, Le Couteur DG, Seibel MJ, Waite LM, Handelsman
DJ. Temporal trend in androgen status and androgensensitive outcomes in older Men. J Clin Endocrinol Metabol 2016; 101:1836-46; https://doi.org/10.1210/ jc.2015-3810

[78] Norman PE, Flicker L, Almeida OP, Hankey GJ, Hyde Z, Jamrozik K. Cohort profile: the health in Men study (HIMS). Int J Epidemiol 2009; 38:48-52; PMID: 18316347; https://doi.org/10.1093/ije/dyn041

[79] Fabbri E, An Y, Gonzalez-Freire M, Zoli M, Maggio M, Studenski SA, Egan JM, Chia CW, Ferrucci L. Bioavailable testosterone linearly declines over a wide age spectrum in Men and Women from the baltimore longitudinal study of aging. J Gerontol A Biol Sci Med Sci 2016.

[80] Ferrini RL, Barrett-Connor E. Sex hormones and age: a cross-sectional study of testosterone and estradiol and their bioavailable fractions in community-dwelling men. Am J Epidemiol 1998; 147:750-4; PMID:9554416; https://doi.org/10.1093/oxfordjou rnals.aje.a009519

[81] Hsu B, Cumming RG, Naganathan V, Blyth FM, Le Couteur DG, Hirani V, Waite LM, Seibel MJ, Handelsman DJ. Temporal changes in androgens and estrogens are associated with all-cause and cause-specific mortality in older Men. J Clin Endocrinol Metabol 2016; 101:2201-10; https://doi.org/10.1210/jc.2016-1025

[82] Camacho EM, Huhtaniemi IT, O’Neill TW, Finn JD, Pye SR, Lee DM, Tajar A, Bartfai G, Boonen S, Casanueva FF, et al. Age-associated changes in hypothalamic-pituitary-testicular function in middle-aged and older men are modified by weight change and lifestyle factors: longitudinal results from the European Male Ageing Study. Euro J Endocrinol / Euro Federat Endocrine Soc 2013; 168:445-55; https://doi.org/ 10.1530/EJE-12-0890

[83] Antonio L, Wu FC, O’Neill TW, Pye SR, Ahern TB, Laurent MR, Huhtaniemi IT, Lean ME, Keevil BG, Rastrelli G, et al. Low free testosterone is associated with hypogonadal signs and symptoms in Men with normal total testosterone. J Clin Endocrinol Metabol 2016:jc20154106.

[84] Yeap BB, Almeida OP, Hyde Z, Norman PE, Chubb SA, Jamrozik K, Flicker L. In men older than 70 years, total testosterone remains stable while free testosterone declines with age. The Health Men Study. Euro J Endocrinol / Euro Federat Endocrine Soc 2007; 156:585-94; https://doi.org/10.1530/EJE-06-0714

[85] Oh JY, Barrett-Connor E, Wedick NM, Wingard DL. Endogenous sex hormones and the development of type 2 diabetes in older men and women: the Rancho Bernardo study. Diab Care 2002; 25:55-60; PMID:11772901; https://doi.org/10.2337/diacare.25.1.55

[86] Mellstrom D, Johnell O, Ljunggren O, Eriksson AL, Lorentzon M, Mallmin H, Holmberg A, Redlund-Johnell I, Orwoll E, Ohlsson C. Free testosterone is an independent predictor of BMD and prevalent fractures in elderly men: MrOS Sweden. J Bone Mineral Res: Off J Am Soc Bone Min Res 2006; 21:529-35; PMID:16598372; https://doi.org/10.1359/jbmr.060110

[87] Cauley JA, Ewing SK, Taylor BC, Fink HA, Ensrud KE, Bauer DC, Barrett-Connor E, Marshall L, Orwoll ES. Sex steroid hormones in older men: longitudinal 
associations with 4.5-year change in hip bone mineral density-the osteoporotic fractures in men study. J Clin Endocrinol Metabol 2010; 95:4314-23; https://doi.org/ 10.1210/jc.2009-2635

[88] Cawthon PM, Schousboe JT, Harrison SL, Ensrud KE, Black D, Cauley JA, Cummings SR, LeBlanc ES, Laughlin GA, Nielson CM, et al. Sex hormones, sex hormone binding globulin, and vertebral fractures in older men. Bone 2016; 84:271-8; PMID:26778261; https://doi.org/ 10.1016/j.bone.2016.01.009

[89] Tajar A, Huhtaniemi IT, O’Neill TW, Finn JD, Pye SR, Lee DM, Bartfai G, Boonen S, Casanueva FF, Forti G, et al. Characteristics of androgen deficiency in late-onset hypogonadism: results from the European Male Aging Study (EMAS). J Clin Endocrinol Metabol 2012; 97:1508-16; https://doi.org/10.1210/jc.2011-2513

[90] Tajar A, Forti G, O’Neill TW, Lee DM, Silman AJ, Finn JD, Bartfai G, Boonen S, Casanueva FF, Giwercman A, et al. Characteristics of secondary, primary, and compensated hypogonadism in aging men: evidence from the European Male Ageing Study. J Clin Endocrinol Metabol 2010; 95:1810-8; https://doi.org/10.1210/ jc.2009-1796

[91] Svartberg J, Midtby M, Bonaa KH, Sundsfjord J, Joakimsen RM, Jorde R. The associations of age, lifestyle factors and chronic disease with testosterone in men: the Tromso Study. Euro J Endocrinol / Euro Federat Endocrine Soc 2003; 149:145-52; https://doi.org/10.1530/ eje. 0.1490145

[92] O'Connor DB, Lee DM, Corona G, Forti G, Tajar A, O’Neill TW, Pendleton N, Bartfai G, Boonen S, Casanueva FF, et al. The relationships between sex hormones and sexual function in middle-aged and older European men. J Clin Endocrinol Metabol 2011; 96:E1577-87; https://doi.org/10.1210/jc.2010-2216

[93] Kupelian V, Shabsigh R, Travison TG, Page ST, Araujo $\mathrm{AB}, \mathrm{McKinlay} J \mathrm{~B}$. Is there a relationship between sex hormones and erectile dysfunction? Results from the Massachusetts Male Aging Study. J Urol 2006; 176:2584-8; PMID:17085164; https://doi.org/10.1016/j. juro.2006.08.020

[94] Hall SA, Shackelton R, Rosen RC, Araujo AB. Risk factors for incident erectile dysfunction among community-dwelling men. J Sex Med 2010; 7:712-22; PMID:19929915; $\quad$ https://doi.org/10.1111/j.17436109.2009.01600.x

[95] Pye SR, Huhtaniemi IT, Finn JD, Lee DM, O’Neill TW, Tajar A, Bartfai G, Boonen S, Casanueva FF, Forti G, et al. Late-onset hypogonadism and mortality in aging men. J Clin Endocrinol Metabol 2014; 99:1357-66; https://doi.org/10.1210/jc.2013-2052

[96] Travison TG, Morley JE, Araujo AB, O’Donnell AB, McKinlay JB. The relationship between libido and testosterone levels in aging men. J Clin Endocrinol Metabol 2006; 91:2509-13; https://doi.org/10.1210/ jc.2005-2508

[97] LeBlanc ES, Wang PY, Janowsky JS, Neiss MB, Fink HA, Yaffe K, Marshall LM, Lapidus JA, Stefanick ML, Orwoll ES. Association between sex steroids and cognition in elderly men. Clin Endocrinol 2010; 72:393-403; PMID:19744108; https://doi.org/10.1111/ j.1365-2265.2009.03692.x
[98] Mohr BA, Bhasin S, Link CL, O’Donnell AB, McKinlay JB. The effect of changes in adiposity on testosterone levels in older men: longitudinal results from the Massachusetts Male Aging Study. Euro J Endocrinol / Euro Federat Endocrine Soc 2006; 155:443-52; https://doi. org/10.1530/eje.1.02241

[99] Derby CA, Zilber S, Brambilla D, Morales KH, McKinlay JB. Body mass index, waist circumference and waist to hip ratio and change in sex steroid hormones: the Massachusetts Male Ageing Study. Clin Endocrinol 2006; 65:125-31; PMID:16817831; https:// doi.org/10.1111/j.1365-2265.2006.02560.x

[100] Wu FC, Tajar A, Pye SR, Silman AJ, Finn JD, O’Neill TW, Bartfai G, Casanueva F, Forti G, Giwercman A, et al. Hypothalamic-pituitary-testicular axis disruptions in older men are differentially linked to age and modifiable risk factors: the European Male Aging Study. J Clin Endocrinol Metabol 2008; 93:2737-45; https://doi.org/ 10.1210/jc.2007-1972

[101] Vikan T, Schirmer H, Njolstad I, Svartberg J. Low testosterone and sex hormone-binding globulin levels and high estradiol levels are independent predictors of type 2 diabetes in men. European journal of endocrinology; European Federation of Endocrine Societies 2010; 162:747-54

[102] Svartberg J, Jenssen T, Sundsfjord J, Jorde R. The associations of endogenous testosterone and sex hormonebinding globulin with glycosylated hemoglobin levels, in community dwelling men. Tromso Study. Diab Metab 2004; 30:29-34; https://doi.org/10.1016/S1262-3636(07) 70086-1

[103] Agledahl I, Skjaerpe PA, Hansen JB, Svartberg J. Low serum testosterone in men is inversely associated with non-fasting serum triglycerides: the Tromso study. Nutrit Metab Cardiovasc Dis: NMCD 2008; 18:256-62; PMID:17560771; https:// doi.org/10.1016/j.numecd.2007.01.014

[104] Kupelian V, Page ST, Araujo AB, Travison TG, Bremner WJ, McKinlay JB. Low sex hormone-binding globulin, total testosterone, and symptomatic androgen deficiency are associated with development of the metabolic syndrome in nonobese men. J. Clin. Endocrinol. Metabol. 2006; 91:843-50; https://doi.org/10.1210/ jc.2005-1326

[105] Barrett-Connor E. Lower endogenous androgen levels and dyslipidemia in men with non-insulin-dependent diabetes mellitus. Annals of internal medicine 1992; 117:807-11; PMID:1416554; https://doi.org/10.7326/ 0003-4819-117-10-807

[106] Barrett-Connor E, Von Muhlen DG, Kritz-Silverstein D. Bioavailable testosterone and depressed mood in older men: the Rancho Bernardo Study. J. Clin. Endocrinol. Metabol. 1999; 84:573-7; https://doi.org/10.1210/ jcem.84.2.5495

[107] Stellato RK, Feldman HA, Hamdy O, Horton ES, McKinlay JB. Testosterone, sex hormone-binding globulin, and the development of type 2 diabetes in middle-aged men: prospective results from the Massachusetts male aging study. Diabetes care 2000; 23:490-4; PMID: 10857940; https://doi.org/10.2337/diacare.23.4.490

[108] Chubb SA, Hyde Z, Almeida OP, Flicker L, Norman PE, Jamrozik K, Hankey GJ, Yeap BB. Lower sex hormone- 
binding globulin is more strongly associated with metabolic syndrome than lower total testosterone in older men: the Health in Men Study. Euro J Endocrinol / Euro Federat Endocrine Soc 2008; 158:785-92; https:// doi.org/10.1530/EJE-07-0893

[109] Yeap BB, Almeida OP, Hyde Z, Norman PE, Chubb SA, Jamrozik K, Hankey GJ, Flicker L. Healthier lifestyle predicts higher circulating testosterone in older men: the Health In Men Study. Clin Endocrinol 2009; 70:45563; PMID:18691270; https://doi.org/10.1111/j.13652265.2008.03372.x

[110] Svartberg J, von Muhlen D, Schirmer H, Barrett-Connor E, Sundfjord J, Jorde R. Association of endogenous testosterone with blood pressure and left ventricular mass in men. The Tromso Study. Euro J Endocrinol / Euro Federat Endocrine Soc 2004; 150:65-71; https://doi.org/ 10.1530/eje.0.1500065

[111] Svartberg J, von Muhlen D, Mathiesen E, Joakimsen O, Bonaa $\mathrm{KH}$, Stensland-Bugge E. Low testosterone levels are associated with carotid atherosclerosis in men. J Int Med 2006; 259:576-82; PMID:16704558; https://doi.org/ 10.1111/j.1365-2796.2006.01637.x

[112] Vikan T, Johnsen SH, Schirmer H, Njolstad I, Svartberg J. Endogenous testosterone and the prospective association with carotid atherosclerosis in men: the Tromso study. Euro J Epidemiol 2009; 24:289-95; PMID:19263227; https://doi.org/10.1007/s10654-0099322-2

[113] Hougaku H, Fleg JL, Najjar SS, Lakatta EG, Harman SM, Blackman MR, Metter EJ. Relationship between androgenic hormones and arterial stiffness, based on longitudinal hormone measurements. Am J Physiol Endocrinol Metab 2006; 290:E234-42; PMID:16159908; https://doi.org/10.1152/ajpendo.00059.2005

[114] Ohlsson C, Barrett-Connor E, Bhasin S, Orwoll E, Labrie F, Karlsson MK, Ljunggren O, Vandenput L, Mellstrom D, Tivesten A. High serum testosterone is associated with reduced risk of cardiovascular events in elderly men. The MrOS (Osteoporotic Fractures in Men) study in Sweden. J Am College Card 2011; 58:1674-81; https://doi.org/10.1016/j.jacc.2011.07.019

[115] Khaw KT, Barrett-Connor E. Blood pressure and endogenous testosterone in men: an inverse relationship. J Hypertension 1988; 6:329-32; PMID:3379300; https://doi.org/10.1097/00004872-198804000-00010

[116] Svartberg J, Jorde R. Endogenous testosterone levels and smoking in men. The fifth Tromso study. Int J Androl 2007; 30:137-43; https://doi.org/10.1111/j.13652605.2006.00720.x

[117] LeBlanc ES, Nielson CM, Marshall LM, Lapidus JA, Barrett-Connor E, Ensrud KE, Hoffman AR, Laughlin G, Ohlsson C, Orwoll ES. The effects of serum testosterone, estradiol, and sex hormone binding globulin levels on fracture risk in older men. J Clin Endocrinol Metabol 2009; 94:3337-46; https://doi.org/10.1210/jc.2009-0206

[118] Vanderschueren D, Pye SR, Venken K, Borghs $\mathrm{H}$, Gaytant J, Huhtaniemi IT, Adams JE, Ward KA, Bartfai G, Casanueva FF, et al. Gonadal sex steroid status and bone health in middle-aged and elderly European men. Osteoporos Int 2010; 21:1331-9; PMID:20012940; https://doi.org/10.1007/s00198-0091144-2
[119] Laughlin GA, Barrett-Connor E, Bergstrom J. Low serum testosterone and mortality in older men. J Clin Endocrinol Metabol 2008; 93:68-75; https://doi.org/ 10.1210/jc.2007-1792

[120] Barrett-Connor E, Laughlin GA, Li H, Nielson CM, Wang PY, Dam TT, Cauley JA, Ensrud KE, Stefanick $\mathrm{ML}$, Lau E, et al. The association of concurrent vitamin $\mathrm{D}$ and sex hormone deficiency with bone loss and fracture risk in older men: the osteoporotic fractures in men (MrOS) study. J Bone Min Res: Off J Am Soc Bone Min Res 2012; 27:2306-13; PMID:22777902; https://doi.org/ $10.1002 /$ jbmr.1697

[121] Ward KA, Pye SR, Adams JE, Boonen S, Vanderschueren D, Borghs H, Gaytant J, Gielen E, Bartfai G, Casanueva $\mathrm{FF}$, et al. Influence of age and sex steroids on bone density and geometry in middle-aged and elderly European men. Osteoporos Int 2011; 22:1513-23; PMID:21052641; https://doi.org/10.1007/s00198-0101437-5

[122] Hsu B, Cumming RG, Seibel MJ, Naganathan V, Blyth FM, Bleicher K, Dave A, Le Couteur DG, Waite LM, Handelsman DJ. Reproductive hormones and longitudinal change in bone mineral density and incident fracture risk in older Men: the concord health and aging in Men project. J Bone Min Res: Off J Am Soc Bone Min Res 2015; 30:1701-8; PMID:25736139; https://doi.org/ 10.1002/jbmr.2493

[123] Roy TA, Blackman MR, Harman SM, Tobin JD, Schrager M, Metter EJ. Interrelationships of serum testosterone and free testosterone index with FFM and strength in aging men. Am J Physiol Endocrinol Metab 2002; 283:E284-94; PMID:12110533; https://doi.org/ 10.1152/ajpendo.00334.2001

[124] Hsu B, Cumming RG, Naganathan V, Blyth FM, Le Couteur DG, Seibel MJ, Waite LM, Handelsman DJ. Longitudinal relationships of circulating reproductive hormone with functional disability, muscle mass, and strength in community-dwelling older men: the Concord Health and Ageing in Men project. J Clin Endocrinol Metabol 2014; 99:3310-8; https://doi.org/10.1210/ jc.2014-1124

[125] O’Donnell AB, Travison TG, Harris SS, Tenover JL, McKinlay JB. Testosterone, dehydroepiandrosterone, and physical performance in older men: results from the Massachusetts Male Aging Study. J Clin Endocrinol Metabol 2006; 91:425-31; https://doi.org/10.1210/ jc.2005-1227

[126] LeBlanc ES, Wang PY, Lee CG, Barrett-Connor E, Cauley JA, Hoffman AR, Laughlin GA, Marshall LM, Orwoll ES. Higher testosterone levels are associated with less loss of lean body mass in older men. J Clin Endocrinol Metabol 2011; 96:3855-63; https://doi.org/ 10.1210/jc.2011-0312

[127] Hyde Z, Flicker L, Almeida OP, Hankey GJ, McCaul KA, Chubb SA, Yeap BB. Low free testosterone predicts frailty in older men: the health in men study. J Clin Endocrinol Metabol 2010; 95:3165-72; https://doi.org/ 10.1210/jc.2009-2754

[128] Travison TG, Nguyen AH, Naganathan V, Stanaway FF, Blyth FM, Cumming RG, Le Couteur DG, Sambrook $\mathrm{PN}$, Handelsman DJ. Changes in reproductive hormone concentrations predict the prevalence and progression 
of the frailty syndrome in older men: the concord health and ageing in men project. J Clin Endocrinol Metabol 2011; 96:2464-74; https://doi.org/10.1210/jc.2011-0143

[129] Cawthon PM, Ensrud KE, Laughlin GA, Cauley JA, Dam TT, Barrett-Connor E, Fink HA, Hoffman AR, Lau E, Lane NE, et al. Sex hormones and frailty in older men: the osteoporotic fractures in men (MrOS) study. J Clin Endocrinol Metabol 2009; 94:3806-15; https://doi. org/10.1210/jc.2009-0417

[130] Moffat SD, Zonderman AB, Metter EJ, Blackman MR, Harman SM, Resnick SM. Longitudinal assessment of serum free testosterone concentration predicts memory performance and cognitive status in elderly men. J Clin Endocrinol Metabol 2002; 87:5001-7; https://doi.org/ 10.1210/jc.2002-020419

[131] Zonderman AB. Predicting Alzheimer's disease in the Baltimore longitudinal study of aging. J Geriatr Psychiatry Neurol 2005; 18:192-5; PMID:16306238; https:/doi. org/10.1177/0891988705281863

[132] Moffat SD, Zonderman AB, Metter EJ, Kawas C, Blackman MR, Harman SM, Resnick SM. Free testosterone and risk for Alzheimer disease in older men. Neurology 2004; 62:188-93; PMID:14745052; https://doi.org/ 10.1212/WNL.62.2.188

[133] Barrett-Connor E, Goodman-Gruen D, Patay B. Endogenous sex hormones and cognitive function in older men. J Clin Endocrinol Metabol 1999; 84:3681-5.

[134] Yeap BB, Almeida OP, Hyde Z, Chubb SA, Hankey GJ, Jamrozik K, Flicker L. Higher serum free testosterone is associated with better cognitive function in older men, while total testosterone is not. The Health In Men Study. Clin Endocrinol 2008; 68:404-12.

[135] Ford AH, Yeap BB, Flicker L, Hankey GJ, Chubb SA, Handelsman DJ, Golledge J, Almeida OP. Prospective longitudinal study of testosterone and incident depression in older men: the health in Men study. Psychoneuroendocrinology 2016; 64:57-65; PMID:26615472; https://doi.org/10.1016/j.psyneuen.2015.11.012

[136] Fonda SJ, Bertrand R, O’Donnell A, Longcope C, McKinlay JB. Age, hormones, and cognitive functioning among middle-aged and elderly men: cross-sectional evidence from the Massachusetts Male Aging Study. J Gerontol A Biol Sci Med Sci 2005; 60:385-90; PMID:15860479; https://doi.org/10.1093/gerona/60.3.385

[137] Hsu B, Cumming RG, Waite LM, Blyth FM, Naganathan V, Le Couteur DG, Seibel MJ, Handelsman DJ. Longitudinal relationships between reproductive hormones and cognitive decline in older Men: the concord health and ageing in Men project. J Clin Endocrinol Metabol 2015; 100:2223-30; https://doi.org/ 10.1210/jc.2015-1016

[138] Hyde Z, Norman PE, Flicker L, Hankey GJ, Almeida OP, McCaul KA, Chubb SA, Yeap BB. Low free testosterone predicts mortality from cardiovascular disease but not other causes: the Health in Men Study. J Clin Endocrinol Metabol 2012; 97:179-89; https://doi.org/ 10.1210/jc.2011-1617

[139] Araujo AB, Kupelian V, Page ST, Handelsman DJ, Bremner WJ, McKinlay JB. Sex steroids and all-cause and cause-specific mortality in men. Arch Int Med 2007; 167:1252-60; PMID:17592098; https://doi.org/ 10.1001/archinte.167.12.1252
[140] Vikan T, Schirmer H, Njolstad I, Svartberg J. Endogenous sex hormones and the prospective association with cardiovascular disease and mortality in men: the tromso study. Euro J Endocrinol/ Euro Federat Endocrine Soc 2009; 161:435-42; https://doi.org/10.1530/ EJE-09-0284

[141] Tivesten A, Vandenput L, Labrie F, Karlsson MK, Ljunggren O, Mellstrom D, Ohlsson C. Low serum testosterone and estradiol predict mortality in elderly men. J Clin Endocrinol Metabol 2009; 94:2482-8; https://doi. org/10.1210/jc.2008-2650

[142] Harman SM, Tsitouras PD. Reproductive hormones in aging men. I. Measurement of sex steroids, basal luteinizing hormone, and Leydig cell response to human chorionic gonadotropin. J Clin Endocrinol Metabol 1980; 51:35-40.

[143] Burns-Cox N, Gingell C. The andropause: fact or fiction? Postgrad Med J 1997; 73:553-6; PMID:9373594; https://doi.org/10.1136/pgmj.73.863.553

[144] Featherstone M, Hepworth M. The history of the male menopause 1848-1936. Maturitas 1985; 7:249-57; PMID:3908882; https://doi.org/10.1016/0378-5122(85) 90047-7

[145] Schultheiss D, Jonas U, Musitelli S. Some historical reflections on the ageing male. World J Urol 2002; 20:40-4; PMID:12088189; https://doi.org/10.1007/s00345002-0254-7

[146] Snyder PJ. Hypogonadism in elderly men-what to do until the evidence comes. N Engl J Med 2004; 350:440-2; PMID:14749451; https://doi.org/10.1056/NEJMp038207

[147] Corona G, Rastrelli G, Maggi M. Diagnosis and treatment of late-onset hypogonadism: systematic review and metaanalysis of TRT outcomes. Best Pract Res Clin Endocrinol Metab 2013; 27:557-79; PMID:24054931; https://doi.org/ 10.1016/j.beem.2013.05.002

[148] Petak SM, Nankin HR, Spark RF, Swerdloff RS, Rodriguez-Rigau LJ. American Association of Clinical Endocrinologists Medical Guidelines for clinical practice for the evaluation and treatment of hypogonadism in adult male patients-2002 update. Endocr Pract 2002; 8:44056; PMID:15260010

[149] Nieschlag EB. H.M. Anamnesis and Physical Examination. In: Nieschlag EB, HM, Nieschlag S, ed. Andrology. Berlin: Springer, 2010:93-100.

[150] Ross A, Bhasin S. Hypogonadism: its prevalence and diagnosis. Urologic Clin North America 2016; 43:163-76; PMID:27132573; https://doi.org/10.1016/j. ucl.2016.01.002

[151] Ahern T, Swiecicka A, Eendebak RJ, Carter EL, Finn JD, Pye SR, O’Neill TW, Antonio L, Keevil B, Bartfai G, et al. Natural history, risk factors and clinical features of primary hypogonadism in ageing men: longitudinal data from the European male ageing study. Clin Endocrinol 2016; PMID:27374987

[152] Rastrelli G, Carter EL, Ahern T, Finn JD, Antonio L, O’Neill TW, Bartfai G, Casanueva FF, Forti G, Keevil B, et al. Development of and recovery from secondary hypogonadism in aging Men: prospective results from the EMAS. J Clin Endocrinol Metabol 2015; 100:317282; https://doi.org/10.1210/jc.2015-1571

[153] Kalyani RR, Gavini S, Dobs AS. Male hypogonadism in systemic disease. Endocrinol Metab Clin North Am 
2007; 36:333-48; PMID:17543722; https://doi.org/ 10.1016/j.ecl.2007.03.014

[154] Lunenfeld B, Mskhalaya G, Zitzmann M, Arver S, Kalinchenko S, Tishova Y, Morgentaler A. Recommendations on the diagnosis, treatment and monitoring of hypogonadism in men. Aging Male: Off J Int Soc Study Aging Male 2015; 18:5-15; PMID:25657080; https://doi. org/10.3109/13685538.2015.1004049

[155] Kim S, Kwon H, Park JH, Cho B, Kim D, Oh SW, Lee CM, Choi HC. A low level of serum total testosterone is independently associated with nonalcoholic fatty liver disease. BMC Gastroenterol 2012; 12:69; PMID:22691278; https://doi. org/10.1186/1471-230X-12-69

[156] Balasubramanian V, Naing S. Hypogonadism in chronic obstructive pulmonary disease: incidence and effects. Curr Opin Pulmonary Med 2012; 18:112-7; PMID:22234275; https://doi.org/10.1097/ MCP.0b013e32834feb37

[157] Mousavi SA, Kouchari MR, Samdani-Fard SH, Gilvaee ZN, Arabi M. Relationship between serum levels of testosterone and the severity of chronic obstructive pulmonary disease. Tanaffos 2012; 11:32-5; PMID:25191426

[158] Svartberg J, Schirmer H, Medbo A, Melbye H, Aasebo $\mathrm{U}$. Reduced pulmonary function is associated with lower levels of endogenous total and free testosterone. The Tromso study. Euro J Epidemiol 2007; 22:107-12; https://doi.org/10.1007/s10654-006-9095-9

[159] Iglesias P, Carrero JJ, Diez JJ. Gonadal dysfunction in men with chronic kidney disease: clinical features, prognostic implications and therapeutic options. J Nephrol 2012; 25:31-42; PMID:21748720; https://doi.org/ 10.5301/JN.2011.8481

[160] Prem AR, Punekar SV, Kalpana M, Kelkar AR, Acharya VN. Male reproductive function in uraemia: efficacy of haemodialysis and renal transplantation. Brit J Urol 1996; 78:635-8; PMID:8944524; https://doi.org/10.1046/ j.1464-410X.1996.14624.x

[161] Albu A, Barbu CG, Antonie L, Vladareanu F, Fica S. Risk factors associated with hypogonadism in beta-thalassemia major patients: predictors for a frequent complication of a rare disease. Postgraduate Med 2014; 126:121-7; PMID:25295656; https://doi.org/10.3810/ pgm.2014.09.2806

[162] Pelusi C, Gasparini DI, Bianchi N, Pasquali R. Endocrine dysfunction in hereditary hemochromatosis. J Endocrinol Investigat 2016; 39:837-47; PMID:26951056; https://doi.org/10.1007/s40618-016-0451-7

[163] Luppa P, Munker R, Nagel D, Weber M, Engelhardt $D$. Serum androgens in intensive-care patients: correlations with clinical findings. Clin Endocrinol 1991; 34:305-10; PMID:1831739; https://doi.org/10.1111/ j.1365-2265.1991.tb03771.x

[164] Woolf PD, Hamill RW, McDonald JV, Lee LA, Kelly M. Transient hypogonadotropic hypogonadism caused by critical illness. J Clin Endocrinol Metabol 1985; 60:44450; https://doi.org/10.1210/jcem-60-3-444

[165] Corona G, Rastrelli G, Maseroli E, Fralassi N, Sforza A, Forti G, Mannucci E, Maggi M. Low testosterone syndrome protects subjects with high cardiovascular risk burden from major adverse cardiovascular events. Andrology 2014; 2:741-7; PMID:25044637; https://doi. org/10.1111/j.2047-2927.2014.00241.x
[166] Rochira V, Diazzi C, Santi D, Brigante G, Ansaloni A, Decaroli MC, De Vincentis S, Stentarelli C, Zona S, Guaraldi G. Low testosterone is associated with poor health status in men with human immunodeficiency virus infection: a retrospective study. Andrology 2015; 3:298-308; PMID:25704864; https://doi.org/10.1111/ andr. 310

[167] Morley JE, Melmed S. Gonadal dysfunction in systemic disorders. Metabol: Clin Exp 1979; 28:1051-73; PMID:386028; https://doi.org/10.1016/0026-0495(79) 90010-6

[168] Spratt DI, Cox P, Orav J, Moloney J, Bigos T. Reproductive axis suppression in acute illness is related to disease severity. J Clin Endocrinol Metabol 1993; 76:1548-54.

[169] Fourrier F, Jallot A, Leclerc L, Jourdain M, Racadot A, Chagnon JL, Rime A, Chopin C. Sex steroid hormones in circulatory shock, sepsis syndrome, and septic shock. Circ Shock 1994; 43:171-8; PMID:7895322

[170] Christeff N, Benassayag C, Carli-Vielle C, Carli A, Nunez EA. Elevated oestrogen and reduced testosterone levels in the serum of male septic shock patients. J Steroid Biochem 1988; 29:435-40; PMID:3374133; https:// doi.org/10.1016/0022-4731(88)90254-3

[171] Travison TG, Shackelton R, Araujo AB, Hall SA, Williams RE, Clark RV, O’Donnell AB, McKinlay JB. The natural history of symptomatic androgen deficiency in men: onset, progression, and spontaneous remission. J Am Geriat Soc 2008; 56:831-9; PMID:18454749; https:// doi.org/10.1111/j.1532-5415.2008.01679.x

[172] Rockwood K, Mitnitski A. Frailty defined by deficit accumulation and geriatric medicine defined by frailty. Clin Geriat Med 2011; 27:17-26; PMID:21093719; https://doi.org/10.1016/j.cger.2010.08.008

[173] Mitnitski A, Collerton J, Martin-Ruiz C, Jagger C, von Zglinicki T, Rockwood K, Kirkwood TB. Age-related frailty and its association with biological markers of ageing. BMC Med 2015; 13:161; PMID:26166298; https:// doi.org/10.1186/s12916-015-0400-x

[174] Armstrong JJ, Mitnitski A, Andrew MK, Launer LJ, White LR, Rockwood K. Cumulative impact of health deficits, social vulnerabilities, and protective factors on cognitive dynamics in late life: a multistate modeling approach. Alzheimer's Res Ther 2015; 7:38; PMID:26052349; https://doi.org/10.1186/s13195-0150120-7

[175] Eichholzer M, Barbir A, Basaria S, Dobs AS, Feinleib M, Guallar E, Menke A, Nelson WG, Rifai N, Platz EA, et al. Serum sex steroid hormones and frailty in older American men of the Third National Health and Nutrition Examination Survey (NHANES III). Aging Male: The Off J Int Soc Study Aging Male 2012; 15:208-15; PMID:22822787; https://doi.org/ $10.3109 / 13685538.2012 .705366$

[176] Tajar A, Lee DM, Pye SR, O'Connell MD, Ravindrarajah R, Gielen E, Boonen S, Vanderschueren D, Pendleton N, Finn JD, et al. The association of frailty with serum 25hydroxyvitamin $\mathrm{D}$ and parathyroid hormone levels in older European men. Age Ageing 2013; 42:352-9; PMID:23111338; https://doi.org/10.1093/ageing/afs162

[177] Ravindrarajah R, Lee DM, Pye SR, Gielen E, Boonen S, Vanderschueren D, Pendleton N, Finn JD, Tajar A, O'Connell MD, et al. The ability of three different 
models of frailty to predict all-cause mortality: results from the European Male Aging Study (EMAS). Arch Gerontol Geriat 2013; 57:360-8; PMID:23871598; https://doi.org/10.1016/j.archger.2013.06.010

[178] Vitale G, Cesari M, Mari D. Aging of the endocrine system and its potential impact on sarcopenia. Euro J Int Med 2016.

[179] Keevil VL, Romero-Ortuno R. Ageing well: a review of sarcopenia and frailty. Proc Nutrit Soc 2015; 74:337-47; PMID:26004622; https://doi.org/ $10.1017 /$ S0029665115002037

[180] Angulo J, El Assar M, Rodriguez-Manas L. Frailty and sarcopenia as the basis for the phenotypic manifestation of chronic diseases in older adults. Mol Aspects Med 2016; 50:1-32; PMID:27370407; https://doi.org/10.1016/ j.mam.2016.06.001

[181] Basualto-Alarcon C, Varela D, Duran J, Maass R, Estrada M. Sarcopenia and androgens: a Link between Pathology and Treatment. Front Endocrinol 2014; 5:217; PMID:25566189

[182] Kizilarslanoglu MC, Kuyumcu ME, Yesil Y, Halil M. Sarcopenia in critically ill patients. J Anesthesia 2016; 30:884-90; PMID:27376823; https://doi.org/10.1007/ s00540-016-2211-4

[183] Trojian TH, Lishnak TS, Heiman D. Epididymitis and orchitis: an overview. Am Fam Physician 2009; 79:5837; PMID:19378875

[184] El-Serafi AT, Osama S, El-Zalat H. IM EL-D. Dysregulation of male sex hormones in chronic hepatitis C patients. Andrologia 2016; 48:82-6; PMID:25912488; https://doi.org/10.1111/and.12425

[185] Deeks SG. HIV infection, inflammation, immunosenescence, and aging. Annu Rev Med 2011; 62:141-55; PMID:21090961; https://doi.org/10.1146/annurev-med042909-093756

[186] Rochira V, Zirilli L, Orlando G, Santi D, Brigante G, Diazzi C, Carli F, Carani C, Guaraldi G. Premature decline of serum total testosterone in HIV-infected men in the HAART-era. PloS One 2011; 6:e28512; PMID:22174826; https://doi.org/10.1371/journal.pone.0028512

[187] Sikaris K, McLachlan RI, Kazlauskas R, de Kretser D, Holden CA, Handelsman DJ. Reproductive hormone reference intervals for healthy fertile young men: evaluation of automated platform assays. J Clin Endocrinol Metabol 2005; 90:5928-36; https://doi.org/10.1210/ jc.2005-0962

[188] Yeap BB, Alfonso H, Chubb SA, Handelsman DJ, Hankey GJ, Norman PE, Flicker L. Reference ranges and determinants of testosterone, dihydrotestosterone, and estradiol levels measured using liquid chromatography-tandem mass spectrometry in a population-based cohort of older men. J Clin Endocrinol Metabol 2012; 97:4030-9; https://doi.org/10.1210/jc.2012-2265

[189] Kloner RA, Carson C, 3rd Dobs A, Kopecky S, Mohler ER, 3rd. Testosterone and cardiovascular disease. J Am College Cardiol 2016; 67:545-57; PMID:26846952; https://doi.org/10.1016/j.jacc.2015.12.005

[190] Corona G, Isidori AM, Buvat J, Aversa A, Rastrelli G, Hackett G, Rochira V, Sforza A, Lenzi A, Mannucci E, et al. Testosterone supplementation and sexual function: a meta-analysis study. J Sex Med 2014; 11:1577-92; PMID:24697970; https://doi.org/10.1111/jsm.12536
[191] Basaria S, Coviello AD, Travison TG, Storer TW, Farwell WR, Jette AM, Eder R, Tennstedt S, Ulloor J, Zhang A, et al. Adverse events associated with testosterone administration. N Engl J Med 2010; 363:109-22; PMID:20592293; https://doi.org/10.1056/ NEJMoa1000485

[192] Finkle WD, Greenland S, Ridgeway GK, Adams JL, Frasco MA, Cook MB, Fraumeni JF, Jr., Hoover RN. Increased risk of non-fatal myocardial infarction following testosterone therapy prescription in men. PloS One 2014; 9:e85805; PMID:24489673; https://doi.org/ 10.1371/journal.pone.0085805

[193] Vigen R, O’Donnell CI, Baron AE, Grunwald GK, Maddox TM, Bradley SM, Barqawi A, Woning G, Wierman ME, Plomondon ME, et al. Association of testosterone therapy with mortality, myocardial infarction, and stroke in men with low testosterone levels. JAMA 2013; 310:1829-36; PMID:24193080; https://doi.org/10.1001/jama.2013.280386

[194] Corona G, Maseroli E, Rastrelli G, Isidori AM, Sforza A, Mannucci E, Maggi M. Cardiovascular risk associated with testosterone-boosting medications: a systematic review and meta-analysis. Expert Opin Drug Saf 2014; 13:1327-51; PMID:25139126; https://doi.org/10.1517/ 14740338.2014.950653

[195] Calof OM, Singh AB, Lee ML, Kenny AM, Urban RJ, Tenover JL, Bhasin S. Adverse events associated with testosterone replacement in middle-aged and older men: a metaanalysis of randomized, placebo-controlled trials. J Gerontol A Biol Sci Med Sci 2005; 60:1451-7; PMID:16339333; https://doi.org/10.1093/gerona/60.11.1451

[196] Haddad RM, Kennedy CC, Caples SM, Tracz MJ, Bolona ER, Sideras K, Uraga MV, Erwin PJ, Montori VM. Testosterone and cardiovascular risk in men: a systematic review and meta-analysis of randomized placebo-controlled trials. Mayo Clin Proc 2007; 82:29-39; PMID:17285783; https://doi.org/10.1016/S0025-6196 (11)60964-6

[197] Fernandez-Balsells MM, Murad MH, Lane M, Lampropulos JF, Albuquerque F, Mullan RJ, Agrwal N, Elamin $\mathrm{MB}$, Gallegos-Orozco JF, Wang AT, et al. Clinical review 1: adverse effects of testosterone therapy in adult men: a systematic review and meta-analysis. J Clin Endocrinol Metabol 2010; 95:2560-75; https://doi.org/ 10.1210/jc.2009-2575

[198] Xu L, Freeman G, Cowling BJ, Schooling CM. Testosterone therapy and cardiovascular events among men: a systematic review and meta-analysis of placebo-controlled randomized trials. BMC Med 2013; 11:108; PMID:23597181; https://doi.org/10.1186/1741-7015-11-108

[199] Same RV, Bell DL, Rosenthal SL, Marcell AV. Sexual and reproductive health care: adolescent and adult men's willingness to talk and preferred approach. Am J Prevent Med 2014; 47:175-81; PMID:24951042; https:// doi.org/10.1016/j.amepre.2014.03.009

[200] Hughes AK, Wittmann D. Aging sexuality: knowledge and perceptions of preparation among U.S. primary care providers. J Sex Marital Ther 2015; 41:304-13; PMID: 24512220; https://doi.org/10.1080/0092623X.2014.889056

[201] Stenholm S, Metter EJ, Roth GS, Ingram DK, Mattison JA, Taub DD, Ferrucci L. Relationship between plasma ghrelin, insulin, leptin, interleukin 6, adiponectin, 
testosterone and longevity in the Baltimore Longitudinal Study of Aging. Aging Clin Exp Res 2011; 23:153-8; PMID:21743292; https://doi.org/10.1007/BF03351078

[202] Austad SN, Fischer KE. Sex Differences in Lifespan. Cell Metabol 2016; 23:1022-33; PMID:27304504; https://doi. org/10.1016/j.cmet.2016.05.019
[203] Nieschlag E, Nieschlag S, Behre HM. Lifespan and testosterone. Nature 1993; 366:215; PMID:8232579; https://doi.org/10.1038/366215a0

[204] Bale TL, Epperson CN. Sex differences and stress across the lifespan. Nat Neurosc. 2015; 18:1413-20; https://doi. org/10.1038/nn.4112 